\title{
Perioperative antibiotics for preventing post-surgical site infections in solid organ transplant recipients (Review)
}

Chan S, Ng S, Chan HP, Pascoe EM, Playford EG, Wong G, Chapman JR, Lim WH, Francis RS, Isbel NM, Campbell SB, Hawley CM, Johnson DW

Chan S, Ng S, Chan HP, Pascoe EM, Playford EG, Wong G, Chapman JR, Lim WH, Francis RS, Isbel NM, Campbell SB, Hawley CM, Johnson DW.

Perioperative antibiotics for preventing post-surgical site infections in solid organ transplant recipients.

Cochrane Database of Systematic Reviews 2020, Issue 8. Art. No.: CD013209.

DOI: 10.1002/14651858.CD013209.pub2.

www.cochranelibrary.com 
TABLE OF CONTENTS

HEADER 1

ABSTRACT

PLAIN LANGUAGE SUMMARY

SUMMARY OF FINDINGS

BACKGROUND

OBJECTIVES

METHODS

RESULTS

Figure 1.

Figure 2.

Figure 3.

DISCUSSION

AUTHORS' CONCLUSIONS

ACKNOWLEDGEMENTS

REFERENCES

CHARACTERISTICS OF STUDIES

HISTORY

CONTRIBUTIONS OF AUTHORS

DECLARATIONS OF INTEREST

DIFFERENCES BETWEEN PROTOCOL AND REVIEW

1

2

3

6

6

6

9

9

10

11

13

13

14

15

18

27

27

27 
[Intervention Review]

\section{Perioperative antibiotics for preventing post-surgical site infections in solid organ transplant recipients}

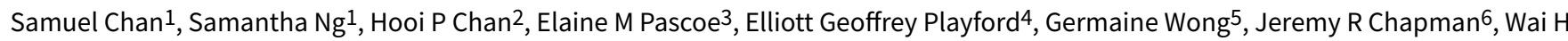
Lim $^{7}$, Ross S Francis ${ }^{1}$, Nicole M Isbel ${ }^{1}$, Scott B Campbell ${ }^{1}$, Carmel M Hawley ${ }^{1}$, David W Johnson ${ }^{1}$

1Department of Nephrology, Princess Alexandra Hospital, Brisbane, Australia. ${ }^{2}$ General Practice Queensland, Brisbane, Australia. ${ }^{3}$ Department of Biostatistics, Faculty of Medicine, The University of Queensland, Brisbane, Australia. ${ }^{4}$ Department of Infection Control Management, Princess Alexandra Hospital, Woolloongabba, Australia. ${ }^{5}$ School of Public Health, The University of Sydney, Sydney, Australia. ${ }^{6}$ Department of Nephrology, Westmead Clinical School, Sydney, Australia. ${ }^{7}$ Department of Nephrology, Sir Charles Gardiner Hospital, Perth, Australia

Contact address: Samuel Chan, samuel.chan@uqconnect.edu.au.

Editorial group: Cochrane Kidney and Transplant Group.

Publication status and date: New, published in Issue 8, 2020.

Citation: Chan S, Ng S, Chan HP, Pascoe EM, Playford EG, Wong G, Chapman JR, Lim WH, Francis RS, Isbel NM, Campbell SB, Hawley CM, Johnson DW. Perioperative antibiotics for preventing post-surgical site infections in solid organ transplant recipients. Cochrane Database of Systematic Reviews 2020, Issue 8. Art. No.: CD013209. DOI: 10.1002/14651858.CD013209.pub2.

Copyright @ 2020 The Cochrane Collaboration. Published by John Wiley \& Sons, Ltd.

\section{A B S T R A C T}

\section{Background}

Solid organ transplant recipients are at high risk for infections due to the complexity of surgical procedures combined with the impact of immunosuppression. No consensus exists on the role of antibiotics for surgical site infections in solid organ transplant recipients.

\section{Objectives}

To assess the benefits and harms of prophylactic antimicrobial agents for preventing surgical site infections in solid organ transplant recipients.

\section{Search methods}

The Cochrane Kidney and Transplant Register of Studies was searched up to 21 April 2020 through contact with the Information Specialist using search terms relevant to this review. Studies in the Register are identified through searches of CENTRAL, MEDLINE, and EMBASE, conference proceedings, the International Clinical Trials Register (ICTRP) Search Portal, and ClinicalTrials.gov.

\section{Selection criteria}

All randomised controlled trials (RCTs) and quasi-RCTs in any language assessing prophylactic antibiotics in preventing surgical site infections in solid organ transplant recipients at any time point after transplantation.

\section{Data collection and analysis}

Two authors independently determined study eligibility, assessed quality, and extracted data. Primary outcomes were surgical site infections and antimicrobial resistance. Other outcomes included urinary tract infections, pneumonias and septicaemia, death (any cause), graft loss, graft rejection, graft function, adverse reactions to antimicrobial agents, and outcomes identified by the Standardised Outcomes of Nephrology Group (SONG), specifically graft health, cardiovascular disease, cancer and life participation. Summary effect estimates were obtained using a random-effects model and results were expressed as risk ratios (RR) and 95\% confidence intervals (CI). The quality of the evidence was assessed using the risk of bias and the GRADE approach. 


\section{Main results}

We identified eight eligible studies ( 718 randomised participants). Overall, five studies (248 randomised participants) compared antibiotics versus no antibiotics, and three studies (470 randomised participants) compared extended duration versus short duration antibiotics. Risk of bias was assessed as high for performance bias (eight studies), detection bias (eight studies) and attrition bias (two studies).

It is uncertain whether antibiotics reduce the incidence of surgical site infections as the certainty of the evidence has been assessed as very low (RR $0.42,95 \% \mathrm{Cl} 0.21$ to 0.85 ; 5 studies, 226 participants; $\mathrm{I}^{2}=25 \%$ ). The certainty of the evidence was very low for all other reported outcomes (death, graft loss, and other infections). It is uncertain whether extended duration antibiotics reduces the incidence of surgical site infections in either solid organ transplant recipients (RR 1.19, 95\% Cl 0.58 to 2.48; 2 studies, 302 participants; $\mathrm{I}^{2}=0 \%$ ) or kidneyonly transplant recipients (RR $0.50,95 \% \mathrm{Cl} 0.05$ to 5.48; 1 study, 205 participants) as the certainty of the evidence has been assessed as very low. The certainty of the evidence was very low for all other reported outcomes (death, graft loss, and other infections). None of the eight included studies evaluated antimicrobial agent adverse reactions, graft health, cardiovascular disease, cancer, life participation, biochemical and haematological parameters, intervention cost, hospitalisation length, or overall hospitalisation costs.

\section{Authors' conclusions}

Due to methodological limitations, risk of bias and significant heterogeneity, the current evidence for the use of prophylactic perioperative antibiotics in transplantation is of very low quality. Further high quality, adequately powered RCTs would help better inform clinical practice.

\section{PLAIN LANGUAGE SUMMARY}

\section{Perioperative antibiotics for preventing post-surgical site infections in solid organ transplant recipients}

\section{What is the issue?}

People receiving organ transplants are at high risk of infections due to the complex surgery and the weakening of the body's immune defence against infection by anti-rejection drugs. The germs causing infection around the time of transplantation may come from the person's body, the transplanted organ, or the environment. Depending on the type of organ transplanted and the era in which the transplant took place, surgical site infections have been reported to occur following $3 \%$ to $53 \%$ of transplant operations. A surgical site infection is an infection that occurs after surgery in the part of the body where the surgery took place. This could include redness of the wound and/or a discharge of pus, which, if not treated with antibiotics or further surgery, could lead to bloodstream infection, infection of other organs in the body (including the transplant organ) or even death. Avoiding surgical site infection may improve patient and transplant survival. Giving antibiotics around the time of the transplant surgery may help to prevent surgical site infections but has not been studied in a systematic way. Giving antibiotics is also not without risk of harm since antibiotics are known to encourage the develop of antibioticresistant germs, cause side effects like diarrhoea, and cost money.

\section{What did we do?}

We reviewed the literature up to April 2020, and found eight studies (718 randomised participants) that assessed whether antibiotics given around the time of transplant surgery prevent surgical site infections in organ transplant recipients.

\section{What did we find?}

When compared with no antibiotics, we are uncertain whether antibiotics reduce the occurrence of surgical site infections as the certainty of the evidence has been assessed as very low. When compared with short duration antibiotics, we are uncertain whether extended duration antibiotics reduce the occurrence of surgical site infections as the certainty of the evidence has been assessed as very low. Studies were limited by small size, short follow-up duration, suboptimal methodological quality, and inconsistent reporting of outcomes. Consequently, the effects of antibiotics in preventing surgical site infections from occurring in people receiving organ transplant is uncertain.

\section{Conclusions}

It is uncertain whether antibiotics are beneficial in solid organ transplant recipients for the prevention of surgical site infections. We do not have enough data to estimate with precision some effects of antibiotics. A randomised controlled trial of antibiotic use versus placebo or single dose versus short course of antibiotic use is warranted. 


\section{SUMMARY OF FINDINGS}

Summary of findings 1. Antibiotics versus no antibiotics for preventing post-surgical site infections in solid organ transplant recipients

Antibiotics versus no antibiotics for preventing post-surgical site infections in solid organ transplant recipients

Patient or population: solid organ transplant recipients

Intervention: antibiotics

Comparison: no antibiotics

\begin{tabular}{|c|c|c|c|c|c|}
\hline \multirow[t]{2}{*}{ Outcomes } & \multicolumn{2}{|c|}{ Anticipated absolute effects ${ }^{*}(95 \% \mathrm{Cl})$} & \multirow{2}{*}{$\begin{array}{l}\text { Relative effect } \\
(95 \% \mathrm{CI})\end{array}$} & \multirow{2}{*}{$\begin{array}{l}\text { No. of par- } \\
\text { ticipants } \\
\text { (studies) }\end{array}$} & \multirow{2}{*}{$\begin{array}{l}\text { Certainty of the } \\
\text { evidence } \\
\text { (GRADE) }\end{array}$} \\
\hline & $\begin{array}{l}\text { Risk with no an- } \\
\text { tibiotics }\end{array}$ & Risk with antibiotics & & & \\
\hline $\begin{array}{l}\text { Surgical site infections* } \\
\text { Time frame: } 2 \text { to } 6 \text { weeks }\end{array}$ & 315 per 1,000 & $\begin{array}{l}132 \text { per } 1,000 \\
(66 \text { to } 268)\end{array}$ & $\begin{array}{l}\text { RR } 0.42 \\
(0.21 \text { to } 0.85)\end{array}$ & $226(5)$ & $\begin{array}{l}\oplus \oplus \Theta \Theta \\
\text { VERY LOW1,2,3 }\end{array}$ \\
\hline $\begin{array}{l}\text { Death (any case) } \\
\text { Time frame: } 2 \text { to } 4 \text { weeks }\end{array}$ & 128 per 1,000 & $\begin{array}{l}35 \text { per } 1,000 \\
(3 \text { to } 473)\end{array}$ & $\begin{array}{l}\text { RR } 0.27 \\
(0.02 \text { to } 3.69)\end{array}$ & $87(2)$ & $\begin{array}{l}\oplus \ominus \Theta \odot \\
\text { VERY LOW } 1,2\end{array}$ \\
\hline $\begin{array}{l}\text { Graft loss (including death with functioning graft) } \\
\text { Time frame: } 2 \text { weeks }\end{array}$ & 37 per 1,000 & $\begin{array}{l}0 \text { per } 1,000 \\
(0 \text { to } 0)\end{array}$ & $\begin{array}{l}\text { RR } 2.89 \\
(0.12 \text { to } 67.96)\end{array}$ & $53(1)$ & $\begin{array}{l}\oplus \odot \Theta \odot \\
\text { VERY LOW } 1,2\end{array}$ \\
\hline $\begin{array}{l}\text { Other infection: UTI } \\
\text { Time frame: } 2 \text { to } 6 \text { weeks }\end{array}$ & 619 per 1,000 & $\begin{array}{l}545 \text { per } 1,000 \\
\text { (421 to } 706)\end{array}$ & $\begin{array}{l}\text { RR } 0.88 \\
\text { (0.68 to } 1.14 \text { ) }\end{array}$ & $150(3)$ & $\begin{array}{l}\oplus \odot \Theta \odot \\
\text { VERY LOW } 1,2\end{array}$ \\
\hline $\begin{array}{l}\text { Other infection: septicaemia } \\
\text { Time frame: } 2 \text { to } 6 \text { weeks }\end{array}$ & 93 per 1,000 & $\begin{array}{l}47 \text { per } 1,000 \\
(10 \text { to } 204)\end{array}$ & $\begin{array}{l}\text { RR } 0.50 \\
\text { (0.11 to } 2.19 \text { ) }\end{array}$ & $90(2)$ & $\begin{array}{l}\oplus \odot \Theta \odot \\
\text { VERY LOW } 1,2\end{array}$ \\
\hline $\begin{array}{l}\text { Other infection: pneumonia } \\
\text { Time frame: up to } 6 \text { weeks }\end{array}$ & 471 per 1,000 & $\begin{array}{l}249 \text { per } 1,000 \\
\text { (99 to } 621 \text { ) }\end{array}$ & $\begin{array}{l}\text { RR } 0.53 \\
\text { (0.21 to } 1.32 \text { ) }\end{array}$ & $37(1)$ & $\begin{array}{l}\oplus \odot \Theta \odot \\
\text { VERY LOW1,2 }\end{array}$ \\
\hline Adverse reactions & Not reported & Not reported & -- & -- & -- \\
\hline
\end{tabular}

${ }^{\star}$ The risk in the intervention group (and its $95 \% \mathrm{Cl}$ ) is based on the assumed risk in the comparison group and the relative effect of the intervention (and its $95 \% \mathrm{Cl}$ ).

Cl: Confidence interval; RR: Risk ratio; UTI: urinary tract infection 


\begin{tabular}{|c|c|c|c|c|c|}
\hline \multicolumn{6}{|c|}{$\begin{array}{l}\text { GRADE Working Group grades of evidence } \\
\text { High certainty: We are very confident that the true effect lies close to that of the estimate of the effect } \\
\text { Moderate certainty: We are moderately confident in the effect estimate: The true effect is likely to be close to the estimate of the effect, but there is a possibility that it is } \\
\text { substantially different } \\
\text { Low certainty: Our confidence in the effect estimate is limited: The true effect may be substantially different from the estimate of the effect } \\
\text { Very low certainty: We have very little confidence in the effect estimate: The true effect is likely to be substantially different from the estimate of effect }\end{array}$} \\
\hline \multicolumn{6}{|c|}{$\begin{array}{l}\text { *No studies attempted to blind participants, personnel, or data analysts. As surgical site infection assessment is partly subjective, we anticipated this would put the results at } \\
\text { risk of being biased in favour of antibiotic treatment } \\
1 \text { Imprecision (small number of study with participants) } \\
2 \text { Study limitations (high risk of performance bias and detection bias) } \\
3 \text { Moderate heterogeneity } \\
\text { Summary of findings } 2 \text {. Extended versus short duration antibiotics for preventing post-surgical site infections in solid organ transplant recipients }\end{array}$} \\
\hline \multicolumn{6}{|c|}{ Extended versus short duration antibiotics for preventing post-surgical site infections in solid organ transplant recipients } \\
\hline \multicolumn{6}{|c|}{$\begin{array}{l}\text { Patient or population: preventing post-surgical site infections in solid organ transplant recipients } \\
\text { Intervention: extended duration antibiotics } \\
\text { Comparison: short duration antibiotics }\end{array}$} \\
\hline \multirow[t]{2}{*}{ Outcomes } & \multicolumn{2}{|c|}{ Anticipated absolute effects* $(95 \% \mathrm{Cl})$} & \multirow{2}{*}{$\begin{array}{l}\text { Relative effect } \\
(95 \% \mathrm{CI})\end{array}$} & \multirow{2}{*}{$\begin{array}{l}\text { No. of par- } \\
\text { ticipants } \\
\text { (studies) }\end{array}$} & \multirow{2}{*}{$\begin{array}{l}\text { Certainty of the } \\
\text { evidence } \\
\text { (GRADE) }\end{array}$} \\
\hline & $\begin{array}{l}\text { Risk with short } \\
\text { duration antibi- } \\
\text { otics }\end{array}$ & $\begin{array}{l}\text { Risk with extended dura- } \\
\text { tion antibiotics }\end{array}$ & & & \\
\hline $\begin{array}{l}\text { Surgical site infections }{ }^{\star} \text { (all) } \\
\text { Time frame: } 30 \text { days }\end{array}$ & 73 per 1,000 & $\begin{array}{l}87 \text { per } 1,000 \\
\text { (42 to } 181)\end{array}$ & $\begin{array}{l}\text { RR } 1.19 \\
\text { (0.58 to } 2.48)\end{array}$ & $302(2)$ & $\begin{array}{l}\oplus \ominus \Theta \odot \\
\text { VERY LOW } 1,2,3\end{array}$ \\
\hline $\begin{array}{l}\text { Surgical site infections: kidney transplant recipients } \\
\text { Time frame: } 30 \text { days }\end{array}$ & 19 per 1,000 & $\begin{array}{l}10 \text { per } 1,000 \\
(1 \text { to } 106)\end{array}$ & $\begin{array}{l}\text { RR } 0.50 \\
(0.05 \text { to } 5.48)\end{array}$ & $205(1)$ & $\begin{array}{l}\oplus \ominus \ominus \odot \\
\text { VERY LOW } 1,2\end{array}$ \\
\hline $\begin{array}{l}\text { Surgical site infections: liver transplant recipients } \\
\text { Time frame: } 30 \text { days }\end{array}$ & 188 per 1,000 & $\begin{array}{l}246 \text { per } 1,000 \\
\text { (114 to } 527)\end{array}$ & $\begin{array}{l}\text { RR } 1.31 \\
\text { (0.61 to } 2.81 \text { ) }\end{array}$ & $97(1)$ & $\begin{array}{l}\oplus \ominus \ominus \ominus \\
\text { VERY LOW } 1,2\end{array}$ \\
\hline $\begin{array}{l}\text { Death (any cause) } \\
\text { Time frame: } 30 \text { days }\end{array}$ & 42 per 1,000 & $\begin{array}{l}8 \text { per } 1,000 \\
(0 \text { to } 166)\end{array}$ & $\begin{array}{l}\text { RR } 0.20 \\
\text { (0.01 to } 3.98 \text { ) }\end{array}$ & $97(1)$ & $\begin{array}{l}\oplus \ominus \ominus \ominus \\
\text { VERY LOW } 1,2\end{array}$ \\
\hline
\end{tabular}




\begin{tabular}{|c|c|c|c|c|c|c|}
\hline 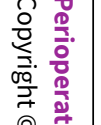 & $\begin{array}{l}\text { Graft loss (including death with functioning graft) } \\
\text { Time frame: } 30 \text { days }\end{array}$ & 93 per 1,000 & $\begin{array}{l}92 \text { per } 1,000 \\
(45 \text { to } 185)\end{array}$ & $\begin{array}{l}\text { RR } 0.99 \\
(0.49 \text { to } 2.00)\end{array}$ & $302(2)$ & $\begin{array}{l}\oplus \ominus \ominus \ominus \\
\text { VERY LOW } 1,2\end{array}$ \\
\hline 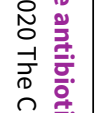 & $\begin{array}{l}\text { Other infection: UTI } \\
\text { Time frame: } 30 \text { days }\end{array}$ & 125 per 1,000 & $\begin{array}{l}61 \text { per } 1,000 \\
\text { (16 to } 231)\end{array}$ & $\begin{array}{l}\text { RR } 0.49 \\
\text { (0.13 to } 1.85)\end{array}$ & $97(1)$ & $\begin{array}{l}\oplus \ominus \ominus \ominus \\
\text { VERY LOW } 1,2\end{array}$ \\
\hline 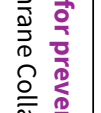 & $\begin{array}{l}\text { Other infection: septicaemia } \\
\text { Time frame: } 30 \text { days }\end{array}$ & 146 per 1,000 & $\begin{array}{l}131 \text { per } 1,000 \\
\text { (74 to } 230)\end{array}$ & $\begin{array}{l}\text { RR } 0.90 \\
\text { (0.51 to } 1.58)\end{array}$ & $302(2)$ & $\begin{array}{l}\oplus \odot \ominus \ominus \\
\text { VERY LOW } 1,2\end{array}$ \\
\hline 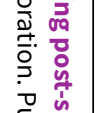 & $\begin{array}{l}\text { Other infection: pneumonia } \\
\text { Time frame: } 30 \text { days }\end{array}$ & No events & $5 / 48^{\star \star}$ & $\begin{array}{l}\text { RR } 10.78 \\
\text { (0.61 to } 189.77 \text { ) }\end{array}$ & $97(1)$ & $\begin{array}{l}\oplus \ominus \ominus \ominus \\
\text { VERY LOW } 1,2\end{array}$ \\
\hline$\frac{0}{0}$ & Adverse reactions & Not reported & Not reported & -- & -- & -- \\
\hline
\end{tabular}

${ }^{*}$ The risk in the intervention group (and its $95 \% \mathrm{Cl}$ ) is based on the assumed risk in the comparison group and the relative effect of the intervention (and its $95 \% \mathrm{Cl}$ ).

Cl: Confidence interval; RR: Risk ratio

\section{GRADE Working Group grades of evidence}

High certainty: We are very confident that the true effect lies close to that of the estimate of the effect

Moderate certainty: We are moderately confident in the effect estimate: The true effect is likely to be close to the estimate of the effect, but there is a possibility that it is substantially different

Low certainty: Our confidence in the effect estimate is limited: The true effect may be substantially different from the estimate of the effect

Very low certainty: We have very little confidence in the effect estimate: The true effect is likely to be substantially different from the estimate of effect

*No studies attempted to blind participants, personnel, or data analysts. As surgical site infection assessment is partly subjective, we anticipated this would put the results at risk of being biased in favour of antibiotic treatment

** Event rate derived from the raw data. A 'per thousand' rate is non-informative in view of the scarcity of evidence and zero events in the control group

1 Imprecision (small number of study with participants)

2Study limitations (high risk of performance bias and detection bias)

3Moderate heterogeneity 


\section{B A C K G R O U N D}

\section{Description of the condition}

Infections following solid organ transplantation are a leading cause of morbidity and death (Fishman 2017; Owens 2008). Depending on the organ transplanted and the era at which the transplant took place, surgical site infections have been reported to occur in 3\% to 53\% of patients transplanted (Choi 2013; Guaraldi 2005). A surgical site infection is an infection that occurs after surgery in the part of the body where the surgery took place. This could include simple erythema of the wound, with subsequent treatment, or return to theatre for wound debridement. The highest rates have been observed in small bowel/multivisceral transplants, where surgical site infection rates can reach over $90 \%$ when prosthetic mesh is used, followed by liver, pancreas, and kidney transplants (Choi 2013; Guaraldi 2005). Surgical site infections are associated with appreciable morbidity, and have been found to extend the average hospital stay by seven days, increase readmission rates, and increase the cost of hospitalisation by nearly 100\% (Hollenbeak 2001; Kirkland 1999). Furthermore, surgical site infections have been associated with increased risks of graft failure and death in solid organ transplant recipients. Moreover, solid organ transplant recipients are at high risk of developing infections with antibiotic-resistant organisms (Linares 2007; Patel 2008; Safdar 2002). Infections with multidrug-resistant organisms have been associated with increased morbidity and death, particularly in solid organ transplant recipients (Linares 2007; Patel 2008). It is therefore crucial that strategies are developed to minimise surgical site infections following transplantation (Evertt 1994; Hellinger 2009; Humar 2001; Loinz 2006; Mattner 2007). The interventions and studies described need to be stratified based on time (era), patient type (organ) and examination of microbiological data.

\section{Description of the intervention}

Administration of one or more antibiotics either as a one-off stat dose or extended for several days around the time of the operation may prevent surgical site infections from occurring following solid organ transplantation.

\section{How the intervention might work}

Antibiotics have commonly been prescribed prior to surgical procedures to try to mitigate the risk of surgical infections (Anesi 2018; Midtvedt 1998; Soave 2001). The principle is that timelimited administration of antibiotics directed against most likely anticipated organisms in the perioperative period will prevent any resident or introduced micro-organisms from developing an established surgical site infection. Although some transplant centres have used antibiotics prophylactically (Tillegard 1984; Townsend 1980) and some guidelines advocate for pre- or perioperative antibiotic prophylaxis (British Columbia Guidelines 2018; Princess Alexandra Hospital 2015), antibiotic use may be associated with significant harm including antibiotic-associated diarrhoea, antibiotic resistance and increasing costs, and thus warrants further study.

\section{Why it is important to do this review}

There is uncertainty regarding the benefits versus harm in using prophylactic antibiotics as a potential strategy for preventing surgical site infections in solid organ transplant recipients (Bratzler 2013; Humar 2005). Specifically, there are no formal recommendations on using perioperative antibiotic prophylaxis in solid organ transplant recipients outside of the clinical practice guidelines for antimicrobial prophylaxis in surgery by the Infectious Diseases Society of America, American Society of Health-System Pharmacists, Surgical Infection Society, and Society for Healthcare Epidemiology of America (IDSA/ASHP/SIS/SHEA). These provide general prophylactic antibiotic recommendations for solid organ transplant recipients, but do not address the unique circumstances of the transplant population (Bratzler 2013). Indeed, the transplant population is a vulnerable group given their increased risk of cardiovascular morbidity and death, and the higher infective risk compared with the general population (Bottomley 2013; Francis 2018).

With the high risk of surgical site infections in solid organ transplant recipients, and a rising incidence of multidrug-resistant organisms in solid organ transplant donors and recipients, it seems logical to progressively broaden and extend perioperative antibiotic prophylaxis. However, the overuse of perioperative antibiotic prophylaxis may lead to a rise in the rates of Clostridium difficile colonization and colitis (Jobe 1995; Kreisel 1995; Privitera 1991), increase the rates of antimicrobial resistance (Roberts 1978) and increase adverse drug reactions as well as increase financial costs. Microbial colonisation patterns are also important in determining appropriate strategies. Consideration needs to be given to the amount and type of organism carried by the donor or the recipient at the clinical centre.

Given the complexities of solid organ transplant recipients and the unique risks for surgical site infections, guidance that is more customised to the solid organ transplant recipient scenario is needed. In the absence of formal guidelines, the aim of this study is to systematically review the evidence of perioperative antibiotics versus placebo or no antibiotics for preventing post-surgical site infections in solid organ transplant recipients.

\section{OB JECTIVES}

To assess the benefits and harms of prophylactic antimicrobial agents for preventing surgical site infections in solid organ transplant recipients.

\section{METHODS}

\section{Criteria for considering studies for this review}

\section{Types of studies}

All randomised controlled trials (RCTs) and quasi-RCTs (RCTs in which allocation to treatment was obtained by alternation, use of alternate medical records, date of birth or other predictable methods) assessing the safety, efficacy, or both of perioperative antibiotics in surgical site infections in solid organ transplant recipients.

\section{Types of participants}

\section{Inclusion criteria}

- Adults and children who receive a solid-organ transplant, including combined grafts (e.g. kidney-pancreas).

\section{Exclusion criteria}

- Pregnant women. 


\section{Types of interventions}

We included studies of any antibiotic medication. The following comparisons were investigated.

- Any antibiotic medication versus placebo or no treatment

- Any antibiotic medication versus any other antibiotic medication

- Low dose versus high dose of the same antibiotic medication

- Short-course versus long-course antibiotic therapy

- Oral versus intravenous administration of the same or different antibiotic medication.

\section{Types of outcome measures}

The outcomes selected include the relevant SONG core outcome sets as specified by the Standardised Outcomes in Nephrology initiative (SONG 2017).

\section{Primary outcomes}

- Surgical site infections

* Stratification by era of study (multi-drug resistance organisms and technical issues)

* Microbiological data regarding resistance for surgical site infections.

\section{Secondary outcomes}

- Death (any cause)

- Graft loss (including death with a functioning graft)

- Incidence of graft rejection at any time point (classified as clinically suspected and treated, or biopsy proven)

- Antimicrobial resistance

- Wound dehiscence/wound exploration

- Other infections (e.g. urinary tract infections (UTI), pneumonia, bacteraemia)

- Graft health

- Cardiovascular disease

- Cancer

- Life participation

- Biochemical and haematological parameters (e.g. C-reactive protein, white cell count (WCC))

- Adverse reactions to antibiotics

- Length of hospitalisation

- Cost of intervention and side-effects

- Overall hospitalisation cost.

\section{Search methods for identification of studies}

\section{Electronic searches}

We searched the Cochrane Kidney and Transplant Register of Studies up to 21 April 2020 through contact with the Information Specialist using search terms relevant to this review. The Register contains studies identified from the following sources.

1. Monthly searches of the Cochrane Central Register of Controlled Trials (CENTRAL)

2. Weekly searches of MEDLINE OVID SP

3. Searches of kidney and transplant journals, and the proceedings and abstracts from major kidney and transplant conferences
4. Searching of the current year of EMBASE OVID SP

5. Weekly current awareness alerts for selected kidney and transplant journals

6. Searches of the International Clinical Trials Register (ICTRP) Search Portal and ClinicalTrials.gov.

Studies contained in the Register are identified through searches of CENTRAL, MEDLINE, and EMBASE based on the scope of Cochrane Kidney and Transplant. Details of search strategies, as well as a list of handsearched journals, conference proceedings and current awareness alerts, are available on the Cochrane Kidney and Transplant website.

See Appendix 1 for search terms used in strategies for this review.

\section{Searching other resources}

1. Reference lists of review articles, relevant studies, and clinical practice guidelines.

2. Contacting relevant individuals/organisations seeking information about unpublished or incomplete studies.

3. Grey literature sources (e.g. abstracts, dissertations, and theses), in addition to those already included in the Cochrane Kidney and Transplant Register of Studies, were not searched.

\section{Data collection and analysis}

\section{Selection of studies}

The search strategy described was used to obtain titles and abstracts of studies that were relevant to the review. The titles and abstracts were screened independently by two authors, who discarded studies that were not applicable, however studies and reviews that might include relevant data or information on studies were retained initially. Two authors independently assessed retrieved abstracts, and if necessary, the full text of these studies, to determine which studies satisfied the inclusion criteria. If there was a disagreement regarding the article validity and inclusion, a tie was broken by a third author.

\section{Data extraction and management}

Data extraction was carried out independently by two authors using standard data extraction forms. Studies reported in non-English language journals were translated before assessment. Where more than one publication of one study existed, reports were grouped together and the publication with the most complete data was used in the analyses. Where relevant outcomes were only published in earlier versions, these data were used. Any discrepancy between published versions was highlighted.

\section{Assessment of risk of bias in included studies}

The following items was independently assessed by two authors using the risk of bias assessment tool (Higgins 2011) (see Appendix 2).

- Was there adequate sequence generation (selection bias)?

- Was allocation adequately concealed (selection bias)?

- Was knowledge of the allocated interventions adequately prevented during the study?

* Participants and personnel (performance bias)

* Outcome assessors (detection bias) 
- Were incomplete outcome data adequately addressed (attrition bias)?

- Are reports of the study free of suggestion of selective outcome reporting (reporting bias)?

- Was the study apparently free of other problems that could put it at a risk of bias?

\section{Measures of treatment effect}

For dichotomous outcomes (incidence of surgical site infection, death, graft loss, incidence of other infections, adverse reactions to antimicrobial agents), results were expressed as risk ratios (RR) with 95\% confidence intervals (Cl). Where continuous scales of measurement were used to assess the effects of treatment (biochemical parameters such as WCC, length of hospitalisation), the mean difference (MD) was used, or the standardised mean difference (SMD) if different scales were used.

\section{Unit of analysis issues}

- Cluster RCTs: if cluster studies have been appropriately analysed to account for clustering in the data, direct measures of effect were extracted if available and used in the meta-analyses using the generic inverse-variance method. If such information was not available, we used cluster-level data as individual units of analysis if the necessary data are available.

- Cross-over studies: we only used data from the first period if these were available.

- Studies with multiple treatment groups: we tried to collapse multiple treatment groups into one where appropriate to enable single pair wise comparison (e.g. collapsing three groups of different doses of antibiotics into one group and include in single pair wise comparison versus placebo) (Higgins 2011).

\section{Dealing with missing data}

Any further information required from the original author was requested by written correspondence (e.g. emailing corresponding author/s) and any relevant information obtained in this manner was to be included in the review. Evaluation of important numerical data, such as screened, randomised patients as well as intention-to-treat, as-treated and per-protocol populations, was carefully performed. Attrition rates, for example due drop-outs, losses to follow-up and withdrawals, were investigated. Issues of missing data and imputation methods (e.g. last-observationcarried-forward) were critically appraised (Higgins 2011).

\section{Assessment of heterogeneity}

We first assessed the heterogeneity by visual inspection of the forest plot. We quantified statistical heterogeneity using the 12 statistic, which described the percentage of total variation across studies that is due to heterogeneity rather than sampling error (Higgins 2003). A guide to the interpretation of $\mathrm{I}^{2}$ values was used as follows.

- $0 \%$ to $40 \%$ : might not be important

- $30 \%$ to $60 \%$ : may represent moderate heterogeneity

- $50 \%$ to $90 \%$ : may represent substantial heterogeneity

- $75 \%$ to $100 \%$ : considerable heterogeneity.

The importance of the observed value of $1^{2}$ depends on the magnitude and direction of treatment effects and the strength of evidence for heterogeneity (e.g. P-value from the $\mathrm{Chi}^{2}$ test, or a $\mathrm{Cl}$ for 12) (Higgins 2011).

\section{Assessment of reporting biases}

Funnel plots were to be used to assess for the potential existence of small study bias (Higgins 2011), however there were insufficient studies to do this.

\section{Data synthesis}

Data were pooled using the random-effects model but the fixedeffect model was also used to ensure robustness of the model chosen and susceptibility to outliers.

\section{Subgroup analysis and investigation of heterogeneity}

Subgroup analyses were planned to explore (if appropriate) possible sources of heterogeneity (participants, interventions, study quality). Heterogeneity among participants could be related to age, sex, time from transplantation to surgical site infections. Heterogeneity in treatments could be related to prior agent(s) used and the agent, dose, and duration of antibiotic therapy. Additionally, heterogeneity could be related to the type of organ transplant (e.g. kidney, liver, lung, pancreas, intestines), as well as the era of transplant (pre-2000 versus post-2000) and the country of origin of the studies. Heterogeneity among bacterial strains could be related to the following conditions.

- Different antibiotics

- Different doses

- Transplant volume at each centre

- Cost of intervention

- Induction immunosuppression choice (e.g. anti-thymocyte globulin versus basiliximab).

Adverse effects were tabulated and assessed with descriptive techniques, as they were likely to be different for the various agents used. Where possible, the risk difference with $95 \% \mathrm{Cl}$ was calculated for each adverse effect, either compared to no treatment or to another agent.

\section{Sensitivity analysis}

Sensitivity analyses were planned to explore the influence of the following factors on effect size.

- Repeating the analysis excluding unpublished studies

- Repeating the analysis taking account of risk of bias, as specified

- Repeating the analysis excluding any very long or large studies to establish how much they dominate the results

- Repeating the analysis excluding studies using the following filters: diagnostic criteria, language of publication, source of funding (industry versus other), and country.

There were insufficient studies to perform these sensitivity analyses.

\section{'Summary of findings' tables}

We have presented the main results of the review in 'Summary of findings' tables. These tables present key information concerning the quality of the evidence, the magnitude of the effects of the interventions examined, and the sum of the available data for the main outcomes (Schunemann 2011a). The 'Summary of 
findings' tables also include an overall grading of the evidence related to each of the main outcomes using the GRADE (Grades of Recommendation, Assessment, Development and Evaluation) approach (GRADE 2008; GRADE 2011). The GRADE approach defines the quality of a body of evidence as the extent to which one can be confident that an estimate of effect or association is close to the true quantity of specific interest. The quality of a body of evidence involves consideration of within-trial risk of bias (methodological quality), directness of evidence, heterogeneity, precision of effect estimates and risk of publication bias (Schunemann 2011b). The following outcomes have been presented in the 'Summary of findings' tables.

- Surgical site infection

* Stratification by era of study (multi-drug resistance organisms and technical issues)

* Microbiological data regarding resistance for surgical site infection
- Death (any cause)

- Graft loss including death with a functioning graft

- Other infections (e.g. UTI, pneumonia, bacteraemia)

- Adverse reactions to antibiotics

\section{Summary of findings and assessment of the certainty of the evidence}

\section{R E S U L T S}

\section{Description of studies}

\section{Results of the search}

We searched the Specialised Register and identified 16 reports. After screening, eight studies (12 reports) were included and three studies (three reports) were excluded. One ongoing study was identified (2007-004284-21). This study and will be assessed in a future update of this review (Figure 1).

Figure 1. Study flow diagram.
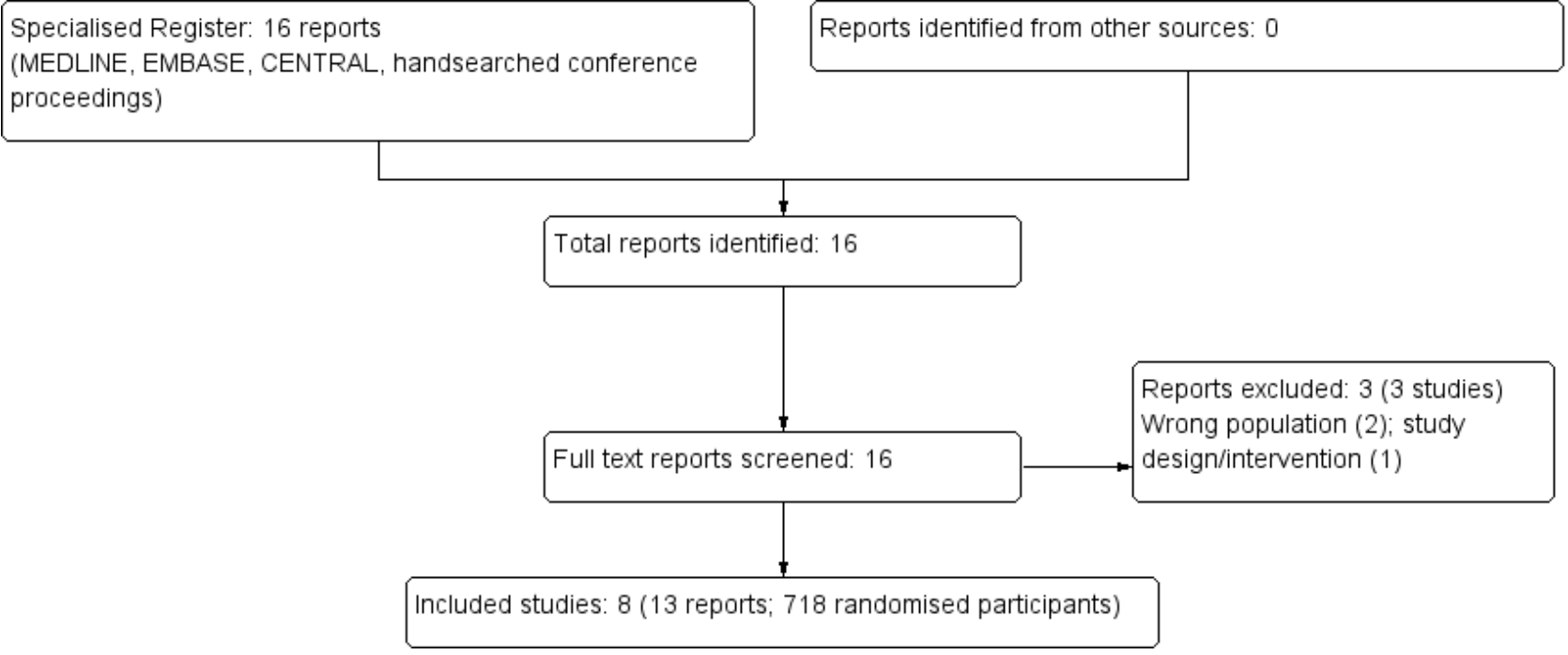

\section{Included studies}

Eight studies (718 randomised participants) were included in this review (Berry 2019; Cohen 1988; Evans 1988; Nikeghbalian 2010; Orlando 2015; Robles 1990; Townsend 1980; Wilms 1986).

Five studies (248 randomised participants) examined the effect of antibiotics versus no antibiotics in the prevention of surgical site infection in solid organ transplant recipients (Cohen 1988; Evans 1988; Robles 1990; Townsend 1980; Wilms 1986). The antibiotics administered were cefuroxime and piperacillin/tazobactam (Cohen 1988), amoxicillin and clavulanic acid (Evans 1988), cefamandole and tobramycin (Townsend 1980), either ceftriaxone or cefotaxime (Robles 1990), or cephalosporin (actual therapy not specified) (Wilms 1986).

Three studies (470 randomised participants) examined the effect of extended antibiotics versus short course antibiotics in the prevention of surgical site infections in solid-organ transplant recipients (Berry 2019; Nikeghbalian 2010; Orlando 2015). The intervention versus control arms were cefazolin every 12 hours or cefotaxime every 12 hours for three or five days, respectively, versus a single dose of cefazolin (Orlando 2015), three-day course of piperacillin/tazobactam every eight hours versus single dose of piperacillin/ tazobactam (Berry 2019), and ceftriaxone and metronidazole versus ampicillin/sulbactam and cefazolin, although the duration of either therapy arms was not specified (Nikeghbalian 2010).

\section{Excluded studies}

Three studies were excluded from this review (Hirokawa 2013; Moreno 1997; Salmela 1990). The reason for exclusion was because of the wrong study population: examining patients with liver resection rather than liver transplantation (Hirokawa 2013); efficacy of antimicrobial therapy upon presentation with a fever 30 days following kidney transplant (Moreno 1997); , or the wrong study outcome (i.e. not assessing surgical site infection (Salmela 1990).

\section{Risk of bias in included studies}

Risks of bias in domains of individual studies are presented in Figure 2 and the summary of risk of bias of all the included studies is presented in Figure 3. 
Figure 2. Risk of bias graph: review authors' judgements about each risk of bias item presented as percentages across all included studies.

Random sequence generation (selection bias) Allocation concealment (selection bias) Blinding of participants and personnel (performance bias): All outcomes Blinding of outcome assessment (detection bias): All outcomes Incomplete outcome data (attrition bias): All outcomes Selective reporting (reporting bias)

Other bias
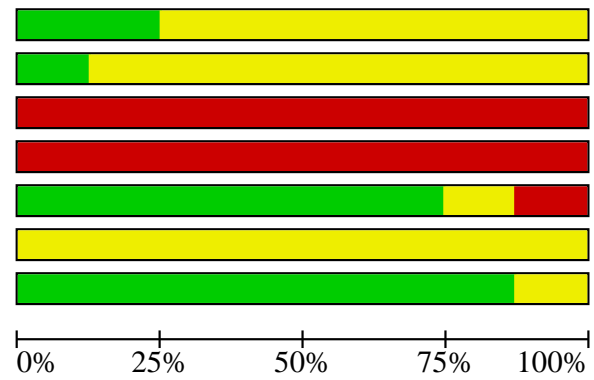
Figure 3. Risk of bias summary: review authors' judgements about each risk of bias item for each included study.

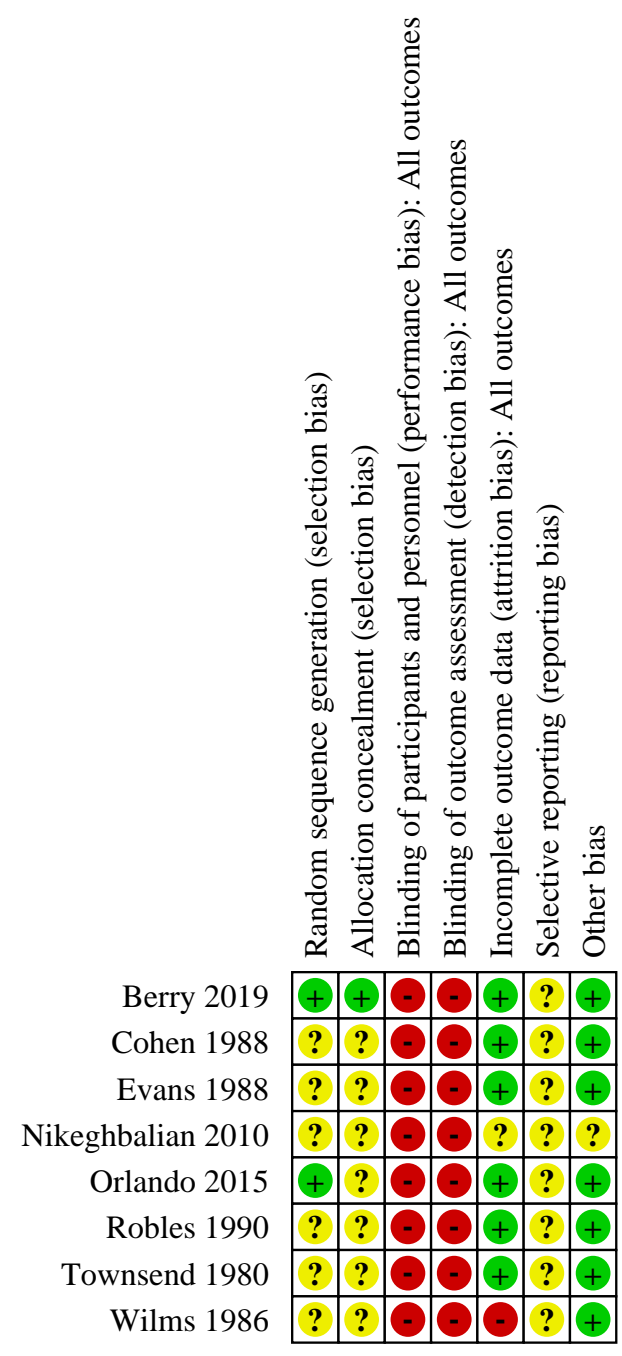

\section{Allocation}

\section{Random sequence generation}

Random sequence generation was judged to be low risk in two studies (Berry 2019; Orlando 2015). The risk of bias was unclear in the remaining six studies.

\section{Allocation concealment}

Allocation concealment was judged to be low risk in one study (Berry 2019). The risk of bias was unclear in the remaining seven studies.

\section{Blinding}

Performance bias (blinding of participants) was judged to be of high risk in all eight studies. Detection bias (blinding of outcomes assessor) was judged to be high risk in all eight studies.

\section{Incomplete outcome data}

Attrition bias was judged to be of low risk in five studies (Cohen 1988; Evans 1988; Berry 2019; Orlando 2015; Robles 1990; Townsend 1980) and at high risk in one studies (Wilms 1986). The risk of bias was unclear in one study (Nikeghbalian 2010).

\section{Selective reporting}

The risk of bias was unclear in all eight studies.

\section{Other potential sources of bias}

All studies were identified as low risk for other potential sources of bias. The risk of sponsorship bias was considered low due to the nature of the research question.

\section{Effects of interventions}

See: Summary of findings 1 Antibiotics versus no antibiotics for preventing post-surgical site infections in solid organ transplant

Perioperative antibiotics for preventing post-surgical site infections in solid organ transplant recipients (Review) 11 
recipients; Summary of findings 2 Extended versus short duration antibiotics for preventing post-surgical site infections in solid organ transplant recipients

\section{Antibiotics versus no antibiotics}

See Summary of findings 1 (antibiotics versus no treatment for preventing surgical site infection in solid organ transplant recipients)

\section{Surgical site infections}

It is uncertain whether antibiotics reduce the incidence of surgical site infection (RR $0.42,95 \% \mathrm{Cl} 0.21$ to $0.85 ; 5$ studies, 226 participants; $12=25 \%$ ) as the certainty of the evidence has been assessed as very low (Analysis 1.1).

\section{Microbiological data regarding resistance for surgical site infections}

Cohen 1988 reported four antibiotic-resistant isolates, two Klebsiella and two Enterobacter, were cultured from infected surgical sites in kidney transplant recipients who received both cefuroxime and piperacillin/tazobactam.

\section{Death (any cause)}

It is uncertain whether antibiotics reduce the incidence of overall death because the certainty of the evidence has been assessed as very low (RR 0.27, 95\% Cl 0.02 to 3.69; 2 studies, 87 participants; I2 $=43 \%$ ) (Analysis 1.2).

\section{Graft loss including death with functioning graft}

It is uncertain whether antibiotics reduce the incidence of graft loss including death with functioning graft because the certainty of the evidence from one study (Cohen 1988) has been assessed as very low (RR 2.89, 95\% Cl 0.12 to $67.96 ; 53$ participants) (Analysis 1.3).

\section{Other infections}

It is uncertain whether antibiotics reduce the incidence of UTIs because the certainty of the evidence has been assessed as very low (RR $0.88,95 \% \mathrm{Cl} 0.68$ to $1.14 ; 3$ studies, 150 participants; $\left.\right|^{2}=0 \%$ ) (Analysis 1.4).

It is uncertain whether antibiotics reduce the incidence of septicaemia because the certainty of the evidence has been assessed as very low (RR $0.50,95 \% \mathrm{Cl} 0.11$ to $2.19 ; 2$ studies, 90 participants; $\mathrm{I}^{2}=0 \%$ ) (Analysis 1.5 ).

It is uncertain whether antibiotics reduce the incidence of pneumonia because the certainty of the evidence from one study (Townsend 1980) has been assessed as very low (RR 0.53, 95\% Cl 0.21 to 1.32 ; 37 participants) (Analysis 1.6).

\section{Extended duration versus short duration antibiotics}

See Summary of findings 2 (extended versus short duration antibiotics for preventing surgical site infection in solid organ transplant recipients)

\section{Surgical site infections}

It is uncertain whether extended duration antibiotics reduces the incidence of surgical site infection because the certainty of the evidence has been assessed as very low (RR $1.19,95 \% \mathrm{Cl} 0.58$ to 2.48; 2 studies, 302 participants; $1^{2}=0 \%$ ) (Analysis 2.1). It is uncertain whether extended duration antibiotics reduces the incidence of surgical site infections in kidney only transplant recipients because the certainty of the evidence from one study (Orlando 2015) has been assessed as very low (RR 0.50, 95\% Cl 0.05 to 5.48; 205 participants) (Analysis 2.1.1). It is uncertain whether extended duration antibiotics reduces the incidence of surgical site infections in liver only transplant recipients because the certainty of the evidence from one study (Berry 2019) has been assessed as very low (RR 1.34, 95\% Cl 0.61 to 2.81; 97 participants) (Analysis 2.1.2).

\section{Microbiological data regarding resistance for surgical site infections}

Five cases of vancomycin-resistant enterococci were found intraabdominally in liver transplant recipients receiving three days of piperacillin/tazobactam compared with one case of vancomycinresistant enterococci found both intra-abdominally and in blood in a liver transplant recipient receiving a stat dose of piperacillin/ tazobactam (Berry 2019). These recipients may already have had vancomycin-resistant enterococci pre-transplant, but this is difficult to ascertain whether resistant organisms were attributed to the use of pre-transplant antibiotics.

\section{Death (any cause)}

It is uncertain whether extended duration antibiotics reduces the incidence of death because the certainty of the evidence from one study (Berry 2019) has been assessed as very low (RR $0.20,95 \% \mathrm{Cl}$ 0.01 to 3.98 ; 97 participants) (Analysis 2.2).

\section{Incidence of graft loss including death with functioning graft}

It is uncertain whether extended duration antibiotics reduces the incidence of graft loss including death with functioning graft because the certainty of the evidence has been assessed as very low (RR $0.99,95 \% \mathrm{Cl} 0.49$ to 2.00; 2 studies, 302 participants; $\left.\right|^{2}=0 \%$ ) (Analysis 2.3)

\section{Other infections}

It is uncertain whether extended duration antibiotics reduces the incidence of UTI because the certainty of the evidence from one study (Berry 2019) has been assessed as very low (RR $0.49,95 \% \mathrm{Cl}$ 0.13 to 1.85 ; 97 participants) (Analysis 2.4).

It is uncertain whether extended duration antibiotics reduces the incidence of septicaemia because the certainty of the evidence has been assessed as very low (RR $0.90,95 \% \mathrm{Cl} 0.51$ to $1.58 ; 2$ studies, 302 participants; $12=0 \%$ ) (Analysis 2.5 ).

It is uncertain whether extended duration antibiotics reduces the incidence of pneumonia because the certainty of the evidence from one study (Berry 2019) has been assessed as very low (RR 10.78, $95 \% \mathrm{Cl} 0.61$ to 189.77 ; 97 participants) (Analysis 2.6).

\section{Wound exploration}

It is uncertain whether extended duration antibiotics reduces the incidence of wound exploration because the certainty of the evidence from one study (Orlando 2015) has been assessed as very low (RR 0.40, $95 \% \mathrm{Cl} 0.08$ to $2.03 ; 205$ participants) (Analysis 2.7 ). 


\section{Other outcomes}

None of the eight included studies evaluated or reported antimicrobial agent adverse reactions, graft health, cardiovascular disease, cancer, life participation, biochemical parameters, haematological parameters, length of hospitalisation, transplant volume at each centre, cost of intervention or overall hospitalisation costs. Additional information was requested from the authors of the eight studies but was not provided.

\section{DISCUSSION}

\section{Summary of main results}

This systematic review has shown that there is insufficient quality evidence to conclude with certainty that antibiotics reduce the incidence of surgical site infections. In the eight included studies, the results had a high degree of heterogeneity, a high risk of bias, and suboptimal methodological design, specifically many single studies, inconsistent comparisons with variable outcome measures (non-patient relevant), and limited data on harms including antibiotic resistance. None of the core outcomes defined by the SONG initiative were reported in any of the eight included studies (Tong 2018). Given the limitations of the available evidence, we were not able to explore and precisely estimate potential complications arising from perioperative antibiotic use.

\section{Overall completeness and applicability of evidence}

Overall, it is difficult to apply the evidence gained from this Cochrane review to clinical practice. First, the included RCTs examined outcomes in kidney and liver transplant recipients, such that the results may not be generalisable to other solid organ transplants, which may have different risks of perioperative infection. In particular, multivisceral transplant patients may be at appreciably higher risk of infections and perioperative antibiotics of longer duration may be required. Second, of the eight included studies, five were published prior to the year 2000 and so may not be applicable to contemporary transplant practice which has seen significant changes in recipient and donor selection, immunosuppressive regimens, infection control practices, and micro-organism resistance patterns and pathogenicity. Third, none of the eight included studies considered the possibility of donor infection/colonisation in guiding antimicrobial management. For example, a study performed in lung transplant recipients found that positive donor bronchoalveolar lavage cultures were associated with longer intensive care unit stays and decreased survival post-transplantation (Roberts 1978). Fourth, only three of the eight included studies reported the resistance patterns of micro-organisms to antimicrobial therapy. This is an important consideration because colonisation may increase the incidence of surgical site infections as noted in heart and lung (Avlonitis 2003), liver (Russell 2008), and kidney (Pouch 2015) transplant recipients. Fifth, the variable, non-standardised definitions of surgical site infections used by the eight studies may lead to misclassification bias. The detection of a surgical site infections depends considerably on how aggressively clinicians investigate them. Surgical site infections are often found post-discharge and are treated in the community, and thus may not detected in the hospital environment.

\section{Quality of the evidence}

The quality of the existing evidence was limited by suboptimal methodological design, specifically a failure to specify methods of randomisation and allocation concealment. In addition, a considerable number of studies had high risks of performance and detection biases. In general, studies were limited by small sample size and an unclear duration of follow-up, which reduced the strength of the review. These limitations suggest that additional studies are likely to change our confidence in the effect estimates (GRADE 2008).

\section{Potential biases in the review process}

The strength of this review is that it included an up-to-date and comprehensive systematic review of previous publications through a thorough MEDLINE, EMBASE and CENTRAL search and included only RCTs or quasi-RCTs, as pre-specified. None of the authors had any commercial conflict of interest related to this review, and although every care was taken to interpret the data as objectively as possible, it is difficult to rule out a subconscious intellectual conflict that may have influenced the conclusions.

\section{Agreements and disagreements with other studies or reviews}

This systematic review has demonstrated that it is uncertain whether antibiotics reduce the incidence of surgical site infections because the certainty of the evidence has been assessed as very low. To the best of our knowledge, there are no published guidelines relating to the use of perioperative antibiotics in solid organ transplant recipients, although there are published recommendations which relate to the general population who are not immunocompromised which also provide some general recommendations for perioperative antibiotic prophylaxis in heart (level A), lung (level A), liver (level B), kidney (level A) and kidney-pancreas (level A) transplantation but not small bowel/ multivisceral transplantation (Bratzler 2013).

\section{AUTHORS' CONCLUSIONS}

\section{Implications for practice}

- Based on currently available data, there is very low certainty evidence to support routinely treating solid organ transplant recipients with antibiotics to prevent surgical site infections.

- The extended duration antibiotic versus short duration antibiotic requires further exploration.

\section{Implications for research}

- Further studies assessing the effects of extended duration antibiotics versus short duration antibiotics on surgical site infections would help inform practice. The current ongoing randomised study may help resolve existing uncertainties. However, different organism-specific transplants need to be considered to provide better estimates to inform clinical practice.

- Future appropriately powered studies are needed to examine the effects of perioperative antibiotics on surgical site infections, UTI, pneumonias and septicaemia, as well as the core outcomes identified by the SONG initiative (Tong 2018).

- Future research should include information on both baseline level of antimicrobial resistance and change in drug resistance 
after antibiotic treatment, using appropriate samples (e.g. rectal swab and urine specimens) and systematic methodology.

\section{ACKNOWLEDGEMENTS}

The authors would like to thank Cochrane Kidney and Transplant for their support during the preparation of this review. The authors are grateful to the following peer reviewers for their time and comments: Amanda J. Vinson (Nova Scotia Health Authority, Division of Nephrology, Department of Medicine, Canada), Nizam Mamode (Professor of Transplant Surgery, Guys Hospital, London, UK), Gregory E. Malat PharmD, FAST, BCPS (Hospital of the University of Pennsylvania, USA). 


\section{RE F E R E N C E S}

\section{References to studies included in this review}

Berry 2019 \{published data only\}

Berry PS, Rosenberger LH, Guidry CA, Agarwal A, Pelletier S, Sawyer RG. Intraoperative versus extended antibiotic prophylaxis in liver transplant surgery: a randomized controlled pilot trial. Liver Transplantation 2019;25(7):1043-53. [MEDLINE: 31063679]

\section{Cohen 1988 \{published data only\}}

Cohen J, Rees AJ, Williams G. A prospective randomized controlled trial of perioperative antibiotic prophylaxis in renal transplantation. Journal of Hospital Infection 1988;11(4):357-63. [MEDLINE: 2899588]

\section{Evans 1988 \{published data only\}}

Evans CM, Purohit S, Colbert JW, Lear PA, Makin T, Scobie DJ, et al. Amoxycillin-clavulanic acid (Augmentin) antibiotic prophylaxis against wound infections in renal failure patients. Journal of Antimicrobial Chemotherapy 1988;22(3):363-9. [MEDLINE: 3053562]

\section{Nikeghbalian 2010 \{published data only\}}

Nikeghbalian S, Kakaei F, Kazemi K, Shamsaeefar A, Sanei B, Bahador A, et al. Comparison of two antibiotic prophylaxis regimens in liver transplant recipients: a randomized clinical trial [abstract no: 337]. Transplantation 2010;90(Suppl 1):803. [EMBASE: 71532666]

Nikeghbalian S, Kakaei F, Kazemi K, Shamsaeefar A, Sanei B, Janghorban $\mathrm{P}$, et al. Comparison of two antibiotic prophylaxis regimens in liver transplant recipients: a randomized clinical trial [abstract no: P-107]. Liver Transplantation 2010;16(Suppl 1):S150. [EMBASE: 70182778]

\section{Orlando 2015 \{published data only\}}

Manzia T, Orlando G, Angelico R, Casella A, Clemente K, De Luca $L$, et al. One-shot versus standard perioperative antibiotic prophylaxis after kidney transplantation: results from a prospective randomized multicenter study [abstract no: B966]. American Journal of Transplantation 2013;13(Suppl 5):320. [EMBASE: 71057542]

Orlando G, Manzia TM, Sorge R, Di Cocco P, Clemente K, Toti L, et al. One-shot versus multidose perioperative antibiotic prophylaxis after kidney transplantation: preliminary results from a prospective randomized multicenter study [abstract no: 984]. American Journal of Transplantation 2010;10(Suppl 4):325.

Orlando G, Manzia TM, Sorge R, laria G, Angelico R, Sforza D, et al. One-shot versus multidose perioperative antibiotic prophylaxis after kidney transplantation: a randomized, controlled clinical trial. Surgery 2015;157(1):104-10. [MEDLINE: 25304836]

Orlando G, Manzia TM, Sorge R, laria G, Angelico R, Sforza D, et al. One-shot versus multidose perioperative antibiotic prophylaxis after kidney transplantation: a randomized, controlled, clinical trial [abstract no: 0268]. Transplant International 2015;28(Suppl 4):99. [EMBASE: 72111510]
Robles 1990 \{published data only\}

Robles NR, Gallego E, Anaya F, Franco A, Valderrabano F. Antibiotic prophylaxis before kidney transplantation. Enfermedades Infecciosas y Microbiologia Clinica 1990;8(2):74-7. [MEDLINE: 2098143]

Townsend 1980 \{published data only\}

Townsend TR, Rudolf LE, Westervelt FB Jr, Mandell GL, Wenzel RP. Prophylactic antibiotic therapy with cefamandole and tobramycin for patients undergoing renal transplantation. Infection Control 1980;1(2):93-6. [MEDLINE: 7033157]

\section{Wilms 1986 \{published data only\}}

Wilms H, Keller F, Hasselmann J, Hantelmann W, Offermann G. Preventive use of antibiotics in kidney transplantation [Antibiotikaprophylaxe bei Nierentransplantation]. Zeitschrift fur Urologie und Nephrologie 1986;79(10):545-8. [MEDLINE: 3544597]

\section{References to studies excluded from this review}

Hirokawa 2013 \{published data only\}

Hirokawa F, Hayashi M, Miyamoto Y, Asakuma M, Shimizu T, Komeda K, et al. Evaluation of postoperative antibiotic prophylaxis after liver resection: a randomized controlled trial. American Journal of Surgery 2013;206(1):8-15. [MEDLINE: 23706259]

\section{Moreno 1997 \{published data only\}}

Moreno A, Vilardell J, Ricart MJ, Claramonte X, Campistol JM, Oppenheimer F. Efficacy of several empirical antibacterial treatment regimens in renal transplant patients with fever [Eficacia de varias pautas de tratamiento empirico antibacteriano en pacientes receptores de trasplante renal con fiebre]. Revista Espanola de Quimioterapia 1997;10(2):138-45. [EMBASE: 27325951]

\section{Salmela 1990 \{published data only\}}

Salmela K, Eklund B, Kyllonen L, Isoniemi H, Korsback C, Hockerstedt K, et al. The effect of intravesically applied antibiotic solution in the prophylaxis of infectious complications of renal transplantation. Transplant International 1990;3(1):12-4. [MEDLINE: 2369474]

\section{Additional references}

\section{Anesi 2018}

Anesi JA, Blumberg EA, Abbo AM. Perioperative antibiotic prophylaxis to prevent surgical site infections in solid organ transplantation. Transplantation 2018;102(1):21-34. [MEDLINE: 28614192]

\section{Avlonitis 2003}

Avlonitis VS, Krause A, Luzzi L, Powell H, Phillips JA, Corris PA, et al. Bacterial colonization of the donor lower airways is a predictor of poor outcome in lung transplantation. European Journal of Cardiothoracic Surgery 2003;24(4):601-7. [MEDLINE: 14500081] 


\section{Bottomley 2013}

Bottomley MJ, Harden PN. Update on the long-term complications of renal transplantation. British Medical Bulletin 2013;106:117-34. [MEDLINE: 23645842]

\section{Bratzler 2013}

Bratzler DW, Dellinger EP, Olsen KM, Perl TM, Auwaerter PG, Bolon MK, et al. Clinical practice guidelines for antimicrobial prophylaxis in surgery. Surgical Infections 2013;14(1):73-156. [MEDLINE: 23461695]

\section{British Columbia Guidelines 2018}

British Columbia Guidelines. Clinical guidelines for kidney transplantation 2018. www.transplant.bc.ca/Documents/Health \%20Professionals/Clinical\%20guidelines/Clinical\%20Guidelines \%20for\%20Kidney\%20Transplantation.pdf (accessed 1 July 2020).

\section{Choi 2013}

Choi SU, Lee JH, Oh CK, Shin GT, Kim H, Kim SJ, et al. Clinical significance of prophylactic antibiotics in renal transplantation. Transplantation Proceedings 2013;45(4):1392-5. [MEDLINE: 23726580]

\section{Evertt 1994}

Evertt JE, Wahoff DC, Statz C, Gillingham KJ, Gruessner A, Gruessner RW, et al. Characterization and impact of wound infection after pancreas transplantation. Archives of Surgery 1994;129(12):1310-6. [MEDLINE: 7986162]

\section{Fishman 2017}

Fishman JA. Infection in organ transplantation. American Journal of Transplantation 2017;17(4):856-79. [MEDLINE: 28117944]

\section{Francis 2018}

Francis A, Johnson DW, Teixeira-Pinto A, Craig JC, Wong G. Incidence and predictors of post-transplant lymphoproliferative disease after kidney transplantation during adulthood and childhood: a registry study. Nephrology Dialysis Transplantation 2018;33(5):881-9. [MEDLINE: 29342279]

\section{GRADE 2008}

Guyatt GH, Oxman AD, Vist GE, Kunz R, Falck-Ytter Y, AlonsoCoello $P$, et al. GRADE: an emerging consensus on rating quality of evidence and strength of recommendations. $B M J$ 2008;336(7650):924-6. [MEDLINE: 18436948]

\section{GRADE 2011}

Guyatt G, Oxman AD, Akl EA, Kunz R, Vist G, Brozek J, et al. GRADE guidelines: 1. Introduction-GRADE evidence profiles and summary of findings tables. Journal of Clinical Epidemiology 2011;64(4):383-94. [MEDLINE: 21195583]

\section{Guaraldi 2005}

Guaraldi C, Cocchi S, Codeluppi M, Di Benedetto F, De Ruvo N, Masetti $\mathrm{M}$, et al. Outcome, incidence and timing of infectious complications in small bowel and multivisceral organ transplantation patients. Transplantation 2005;80(12):1742-8. [MEDLINE: 16378070]

\section{Hellinger 2009}

Hellinger WC, Crook JE, Heckman MG, Diehl NN, Shalev JA, Zubair AC, et al. Surgical site infection after liver transplantation: risk factors and association with graft loss or death. Transplantation 2009;87(9):1387-93. [MEDLINE: 19424041]

\section{Higgins 2003}

Higgins JP, Thompson SG, Deeks JJ, Altman DG. Measuring inconsistency in meta-analyses. BMJ 2003;327(7414):557-60. [MEDLINE: 12958120]

\section{Higgins 2011}

Higgins JP, Green S (editors). Cochrane Handbook for Systematic Reviews of Interventions Version 5.1.0 [updated March 2011]. The Cochrane Collaboration, 2011. Available from www.cochrane-handbook.org.

\section{Hollenbeak 2001}

Hollenbeak CS, Alfrey EJ, Souba WW. The effect of surgical site infections on outcomes and resource utilization after liver transplantation. Surgery 2001;130(2):388-95. [MEDLINE: 11490376]

\section{Humar 2001}

Humar A, Ramcharan T, Denny R, Gillingham KJ, Payne WD, Matas AJ. Are wound complications after a kidney transplant more common with modern immunosuppression? Transplantation 2001;72(12):1920-3. [MEDLINE: 11773889]

\section{Humar 2005}

Humar A, Matas AJ. Surgical complications after kidney transplantation. Seminars in Dialysis 2005;15(6):505-10. [MEDLINE: 16398714]

\section{Jobe 1995}

Jobe BA, Grasley A, Deveney KE, Deveney CW, Sheppard BC. Clostridium difficile colitis: an increasing hospital-acquired illness. American Journal of Surgery 1995;169(5):480-3. [MEDLINE: 7747823]

\section{Kirkland 1999}

Kirkland KB, Briggs JP, Trivette SL, Wilkinson WE, Sexton DJ. The impact of surgical-site infections in the 1990s: attributable mortality, excess length of hospitalization and extra costs. Infection Control \& Hospital Epidemiology 1999;20(11):725-30. [MEDLINE: 10580621]

\section{Kreisel 1995}

Kreisel D, Savel TG, Silver AL, Cunningham JD. Surgical antibiotic prophylaxis and Clostridium difficile toxin positivity. Archives of Surgery 1995;130(9):989-93. [MEDLINE: 7661686]

\section{Linares 2007}

Linares L, Cervera C, Cofan F, Ricart MJ, Esforzado N, Torregrosa $\mathrm{V}$, et al. Epidemiology and outcomes of multiple antibiotic-resistant bacterial infection in renal transplantation. Transplantation Proceedings 2007;39(7):2222-4. [MEDLINE: $17889144]$ 


\section{Loinz 2006}

Loinz C, Kato T, Nishida S, Weppler D, Levi D, Dowdy L, et al. Bacterial infections after intestine and multivisceral transplantation. The experience of the University of Miami (1994-2001). Hepato-Gastroenterology 2006;53(68):234-42. [MEDLINE: 16608031]

\section{Mattner 2007}

Mattner F, Fischer S, Weissbrodt H, Chaberny IF, Sohr D, Gottlieb J, et al. Post-operative nosocomial infections after lung and heart transplantation. Journal of Heart \& Lung Transplantation 2007;26(3):241-9. [MEDLINE: 17346626]

\section{Midtvedt 1998}

Midtvedt K, Hartmann A, Midtvedt T, Brekke IB. Routine perioperative antibiotic prophylaxis in renal transplantation. Nephrology Dialysis Transplantation 1998;13(7):1637-41. [MEDLINE: 9681704]

\section{Owens 2008}

Owens CD, Stoessel K. Surgical site infections: epidemiology, microbiology and prevention. Journal of Hospital Infection 2008;70 Suppl 2:3-10. [MEDLINE: 19022115]

\section{Patel 2008}

Patel G, Huprikar S, Factor SH, Jenkins SG, Calfee DP. Outcomes of carbapenem-resistant Klebsiella pneumoniae infection and the impact of antimicrobial and adjunctive therapies. Infection Control \& Hospital Epidemiology 2008;29(12):1099-106. [MEDLINE: 18973455]

\section{Pouch 2015}

Pouch SM, Kubin CJ, Satlin MJ, Tsapepas DS, Lee JR, Dube G, et al. Epidemiology and outcomes of carbapenem-resistant Klebsiella pneumoniae bacteriuria in kidney transplant recipients. Transplant Infectious Diseases 2015;17(6):800-9. [MEDLINE: 26341757]

\section{Princess Alexandra Hospital 2015}

Princess Alexandra Hospital. Princess Alexandra Hospital Renal Transplant Surgical Antibiotic Prophylaxis Guidelines. Version 1; August 2015. www.metrosouth.health.qld.gov.au/sites/default/ files/content/pah-renal-transplant.pdf (accessed 1 July 2020).

\section{Privitera 1991}

Privitera G, Scarpellini P, Ortisi G, Nicastro G, Nicolin R, de Lalla F. Prospective study of Clostridium difficile intestinal colonization and disease following single-dose antibiotic prophylaxis in surgery. Antimicrobial Agents \& Chemotherapy 1991;35(1):208-10. [MEDLINE: 2014978]

\section{Roberts 1978}

Robert NJ Jr, Douglas RG Jr. Gentamicin use and Pseudomonas and Serratia resistance: effect of a surgical prophylaxis regimen. Antimicrobial Agents \& Chemotherapy 1978;13(2):214-20. [MEDLINE: 348094]

\section{Russell 2008}

Russell DL, Flood A, Zaroda TE, Acosta C, Riley MM, Busuttil RW, et al. Outcomes of colonization with MRSA and VRE among liver transplant candidates and recipients. American Journal of Transplantation 2008;8(8):1737-43. [MEDLINE: 18557723]

\section{Safdar 2002}

Safdar N, Maki DG. The commonality of risk factors for nosocomial colonization and infection with antimicrobialresistant Staphylococcus aureus, Enterococcus, gram-negative bacilli, Clostridium difficile, and Candida. Annals of Internal Medicine 2002;136(11):834-44. [MEDLINE: 12044132]

\section{Schunemann 2011a}

Schünemann HJ, Oxman AD, Higgins JP, Vist GE, Glasziou P, Guyatt GH. Chapter 11: Presenting results and 'Summary of findings' tables. In: Higgins JP, Green S (editors). Cochrane Handbook for Systematic Reviews of Interventions Version 5.1.0 [updated March 2011]. The Cochrane Collaboration, 2011. Available from www.cochrane-handbook.org.

\section{Schunemann 2011b}

Schünemann HJ, Oxman AD, Higgins JP, Deeks JJ, Glasziou P, Guyatt GH. Chapter 12: Interpreting results and drawing conclusions. In: Higgins JP, Green S (editors). Cochrane Handbook for Systematic Reviews of Interventions Version 5.1.0 [updated March 2011]. The Cochrane Collaboration, 2011. Available from www.cochrane-handbook.org.

\section{Soave 2001}

Soave R. Prophylaxis strategies for solid-organ transplantation. Clinical Infectious Diseases 2001;33 Suppl 1:S26-31. [MEDLINE: 11389519]

\section{SONG 2017}

SONG Initiative. The SONG Handbook Version 1.0. 2017. www.songinitiative.org/reports-and-publications/ (accessed 1 July 2020).

\section{Tillegard 1984}

Tillegard A. Renal transplant wound infection: the value of prophylactic antibiotic treatment. Scandinavian Journal of Urology \& Nephrology 1984;18(3):215-21. [MEDLINE: 6387898]

\section{Tong 2018}

Tong A, Sautenet B, Poggio E, Lentine KL, Oberbauer R, Mannon R, et al. Establishing a core outcome measure for graft health: a standardized outcomes in nephrology - kidney transplantation (SONG-Tx) Consensus Workshop Report. Transplantation 2018;102(8):1358-66. [MEDLINE: 29470347]

\section{References to other published versions of this review \\ Chan 2018}

Chan S, Ng S, Chan HP, Pascoe E, Playford EG, Wong G, et al. Perioperative antibiotics for preventing post-surgical site infections in solid organ transplant recipients. Cochrane Database of Systematic Reviews 2018, Issue 12. Art. No: CD013209. [DOI: 10.1002/14651858.CD013209] 
CHARACTERISTICS OF STUDIES

Characteristics of included studies [ordered by study ID]

Berry 2019

\section{Study characteristics}

\begin{tabular}{|c|c|}
\hline Methods & $\begin{array}{l}\text { - Study design: single-centre, open-label, parallel RCT } \\
\text { - Recruitment period: } 1 \text { July } 2010 \text { to } 15 \text { October } 2015 \\
\text { - Duration of follow-up: up to } 30 \text { days post operation }\end{array}$ \\
\hline Participants & $\begin{array}{l}\text { - Country: USA } \\
\text { - Setting: single centre } \\
\text { - Inclusion criteria: liver transplant } \\
\text { - Number (randomised/ analysed): } 102 / 97 \text {; treatment group (51/49); control group (51/48) } \\
\text { - Sex (M/F): treatment group 30/19; control group; } 39 / 9 \\
\text { - Mean age, range (years): treatment group } 56 \text { ( } 51 \text { to } 58 \text { ); control group } 58.5 \text { ( } 55 \text { to } 61 \text { ) } \\
\text { - Exclusion criteria: < } 18 \text { years; previous liver transplant or if the transplant had occurred during a hos- } \\
\text { pital admission for any reason other than planned transplantation; active infection at the time of liver } \\
\text { transplant (defined as requiring treatment antimicrobials at the time of transplantation and agreed } \\
\text { upon by both the principal investigator and the transplant surgeon performing the procedure) }\end{array}$ \\
\hline Interventions & $\begin{array}{l}\text { Treatment group } \\
\text { - Extended 3-day course of piperacillin/tazobactam every } 8 \text { hours } \\
\text { Control group } \\
\text { - Piperacillin/tazobactam at the time of anaesthesia }\end{array}$ \\
\hline
\end{tabular}

Primary outcome
- Rate of surgical site infections and nosocomial infections
Secondary outcomes
- ICU and hospital length of stay
- Rates of readmission and re-operation
- Time to infection

Notes - Funding source: not reported

\section{Risk of bias}

\begin{tabular}{lll}
\hline Bias & Authors' judgement & Support for judgement \\
\hline $\begin{array}{l}\text { Random sequence genera- } \\
\text { tion (selection bias) }\end{array}$ & Low risk & $\begin{array}{l}\text { Quote: "patients were randomised in a 1:1 fashion and assigned to either EA or } \\
\text { SA by block randomisation in groups of 10" }\end{array}$ \\
\hline $\begin{array}{l}\text { Allocation concealment } \\
\text { (selection bias) }\end{array}$ & Low risk & $\begin{array}{l}\text { Quote: "the study-group assignments were placed in sealed, opaque, random- } \\
\text { ly assorted envelopes, which were opened at the time of transplantation" }\end{array}$ \\
\hline $\begin{array}{l}\text { Blinding of participants } \\
\text { and personnel (perfor- } \\
\text { mance bias) } \\
\text { All outcomes }\end{array}$ & High risk & $\begin{array}{l}\text { There is no mention of whether there was blinding of participants and person- } \\
\text { nel in this article }\end{array}$ \\
\hline
\end{tabular}


Berry 2019 (Continued)

Blinding of outcome as- High risk There is no mention of whether the outcome assessment was blinded sessment (detection bias)

All outcomes

\begin{tabular}{lll}
\hline $\begin{array}{l}\text { Incomplete outcome data } \\
\text { (attrition bias) } \\
\text { All outcomes }\end{array}$ & Low risk & All participants completed each outcome assessment \\
\hline $\begin{array}{l}\text { Selective reporting (re- } \\
\text { porting bias) }\end{array}$ & Unclear risk & $\begin{array}{l}\text { Without a study protocol, it is unclear whether any outcomes were measured } \\
\text { but not reported based on the results }\end{array}$
\end{tabular}

\begin{tabular}{ll}
\hline Other bias $\quad$ Low risk $\quad$ No other sources of bias identified \\
\hline
\end{tabular}

Cohen 1988

\section{Study characteristics}

\begin{tabular}{|c|c|}
\hline Methods & $\begin{array}{l}\text { - Study design: prospective RCT } \\
\text { - Recruitment period: January } 1984 \text { to December } 1985 \\
\text { - Duration of follow-up: } 14 \text { days }\end{array}$ \\
\hline Participants & $\begin{array}{l}\text { - Country: UK } \\
\text { - Setting: single centre } \\
\text { - Inclusion criteria: all patients who underwent kidney transplantation at Hammersmith Hospital be- } \\
\text { tween January } 1984 \text { and December } 1985 \\
\text { - Number (randomised/ analysed): } 53 / 53 \text {; treatment group }(27) \text {; control group }(26) \\
\text { - Sex (M/F): treatment group }(17 / 10) \text {; control group }(17 / 9) \\
\text { - Mean age } \pm S D \text { (years): treatment group }(49.1 \pm 11.1) \text {; control group }(38.8 \pm 14.8) \\
\text { - Exclusion criteria: aged < } 15 \text { years and adults }<40 \mathrm{~kg} \text {; clear history of hypersensitivity to penicillin or } \\
\text { cephalosporin; antibiotic treatment of any kind during the preceding } 7 \text { days }\end{array}$ \\
\hline
\end{tabular}

Treatment group
$\begin{aligned} & \text { Interventions } \\ & \text { Three doses of cefuroxime } 750 \mathrm{mg} \text { and piperacillin } 4 \mathrm{~g} \text { IV, the first at induction of anaesthesia and } 2 \\ & \text { Control group } \\ & \text { - No antibiotics }\end{aligned}$

\begin{tabular}{ll}
\hline Outcomes & $\cdot$ Clinically significant, microbiologically confirmed infections \\
\hline Notes & Funding source: not reported
\end{tabular}

\section{Risk of bias}

\begin{tabular}{lll}
\hline Bias & Authors' judgement & Support for judgement \\
\hline $\begin{array}{l}\text { Random sequence genera- } \\
\text { tion (selection bias) }\end{array}$ & Unclear risk & $\begin{array}{l}\text { The article states that "patients were randomised", but there is no mention of } \\
\text { how the patients were randomised }\end{array}$ \\
\hline $\begin{array}{l}\text { Allocation concealment } \\
\text { (selection bias) }\end{array}$ & Unclear risk & $\begin{array}{l}\text { It is not reported whether allocation concealment was performed in this study; } \\
\text { for example, whether envelopes were used and if they were, whether the en- } \\
\text { velopes used to allocate participants were sealed and sequentially numbered }\end{array}$ \\
\hline
\end{tabular}


Cohen 1988 (Continued)

Blinding of participants High risk There is no mention of whether there was blinding of participants and personand personnel (perfornel

mance bias)

All outcomes

\section{Blinding of outcome as- High risk}

There is no mention of whether the outcome assessment was blinded sessment (detection bias)

All outcomes

Incomplete outcome data Low risk

(attrition bias)

All participants completed each outcome assessment

All outcomes

\begin{tabular}{|c|c|c|}
\hline $\begin{array}{l}\text { Selective reporting (re- } \\
\text { porting bias) }\end{array}$ & Unclear risk & $\begin{array}{l}\text { Without a study protocol, it is unclear whether any outcomes were measured } \\
\text { but not reported based on the results }\end{array}$ \\
\hline
\end{tabular}

Otherbias

Other bias

Low risk

No other sources of bias identified

Evans 1988

\section{Study characteristics}

\begin{tabular}{ll}
\hline Methods & Study design: RCT \\
- Recruitment period: January 1983 to July 1983 \\
- \\
\hline Participants \\
- Country: UK \\
- Setting: Single centre \\
- Inclusion criteria: dialysis patients undergoing kidney transplantation were considered for entry into \\
the study (i.e. those who were on HD and PD, who were undergoing live related or cadaveric trans- \\
tomy, or laparotomy for PD access or for GI surgery \\
- Number (randomised/ analysed): 52/46; treatment group (24); control group (22) \\
- Sex (M/F): treatment group (13/11); control group (17/5) \\
- Mean age (years): treatment group (39); control group (42) \\
- Exclusion criteria: allergic to penicillin (or its derivatives) and who were already receiving a course of \\
antibiotic therapy
\end{tabular}

\begin{tabular}{ll}
\hline Interventions & Treatment group \\
& - $1.0 \mathrm{~g}$ amoxicillin and $200 \mathrm{mg}$ clavulanic acid IV, on induction and again on reversal of anaesthesia \\
& Control group \\
& - No antibiotic cover \\
\hline Outcomes & Presence of wound infection (collection of pus or infected drainage from wound within 1 month of \\
& surgery) \\
\hline Notes & Funding source: not reported
\end{tabular}

\section{Risk of bias}




\section{Evans 1988 (Continued)}

Random sequence genera- Unclear risk tion (selection bias)

Allocation concealment Unclear risk
(selection bias)

The article states that "patients were randomised", but there is no mention of how the patients were randomised
It is not reported whether allocation concealment was performed in this study; for example, whether envelopes were used and if they were, whether the envelopes used to allocate participants were sealed and sequentially numbered
Blinding of participants High risk and personnel (performance bias)

All outcomes
There is no mention of whether there was blinding of participants and personnel in this article

\begin{tabular}{lll}
$\begin{array}{l}\text { Blinding of outcome as- } \\
\text { sessment (detection bias) } \\
\text { All outcomes }\end{array}$ & High risk & There is no mention of whether the outcome assessm \\
\hline $\begin{array}{l}\text { Incomplete outcome data } \\
\text { (attrition bias) }\end{array}$ & Low risk & All participants completed each outcome assessment \\
All outcomes &
\end{tabular}

\begin{tabular}{lll}
\hline $\begin{array}{l}\text { Selective reporting (re- } \\
\text { porting bias) }\end{array}$ & Unclear risk & $\begin{array}{l}\text { Without a study protocol, it is unclear whether any outcomes were measured } \\
\text { but not reported based on the results }\end{array}$ \\
\hline Other bias & Low risk & No other sources of bias identified \\
\hline
\end{tabular}

Nikeghbalian 2010

\section{Study characteristics}

\begin{tabular}{|c|c|}
\hline Methods & $\begin{array}{l}\text { - Study design: RCT } \\
\text { - Recruitment period: November } 2008 \text { to November } 2009 \\
\text { - Duration of follow-up: not reported }\end{array}$ \\
\hline Participants & $\begin{array}{l}\text { - Country: Iran } \\
\text { - Setting: single centre } \\
\text { - Inclusion criteria: liver transplant recipients } \\
\text { - Number (randomised/ analysed): "163 patients meet our inclusion criteria" } \\
\text { - Sex (M/F): not reported } \\
\text { - Mean age } \pm \text { SD (years): } \text { not reported } \\
\text { - Exclusion criteria: not reported }\end{array}$ \\
\hline Interventions & $\begin{array}{l}\text { Treatment group } \\
\text { - Ceftriaxone and metronidazole for antibacterial prophylaxis } \\
\text { Control group } \\
\text { - Ampicillin-sulbactam and ceftizoxime for antibacterial prophylaxis }\end{array}$ \\
\hline Outcomes & - Bacterial infections in the hospital course \\
\hline Notes & $\begin{array}{l}\text { - Abstract-only publication } \\
\text { - Funding source: not reported }\end{array}$ \\
\hline
\end{tabular}


Nikeghbalian 2010 (Continued)

\section{Risk of bias}

\begin{tabular}{lll}
\hline Bias & Authors' judgement & Support for judgement \\
\hline $\begin{array}{l}\text { Random sequence genera- } \\
\text { tion (selection bias) }\end{array}$ & Unclear risk & Attempts to contact corresponding author failed \\
\hline $\begin{array}{l}\text { Allocation concealment } \\
\text { (selection bias) }\end{array}$ & Unclear risk & Attempts to contact corresponding author failed \\
\hline $\begin{array}{l}\text { Blinding of participants } \\
\text { and personnel (perfor- } \\
\text { mance bias) }\end{array}$ & High risk & $\begin{array}{l}\text { This study was not blinded (as there were different dosing frequencies and } \\
\text { routes of administration) }\end{array}$ \\
\hline $\begin{array}{l}\text { Blinding of outcome as- } \\
\text { sessment (detection bias) } \\
\text { All outcomes }\end{array}$ & High risk & $\begin{array}{l}\text { This study was not blinded (as there were different dosing frequencies and } \\
\text { routes of administration) }\end{array}$ \\
\hline $\begin{array}{l}\text { Incomplete outcome data } \\
\text { (attrition bias) } \\
\text { All outcomes }\end{array}$ & Unclear risk & Attempts to contact corresponding author failed \\
\hline $\begin{array}{l}\text { Selective reporting (re- } \\
\text { porting bias) }\end{array}$ & Unclear risk & Attempts to contact corresponding author failed \\
\hline \begin{tabular}{l} 
Other bias \\
\hline
\end{tabular} & Unclear risk & Attempts to contact corresponding author failed \\
\hline
\end{tabular}

\section{Orlando 2015}

\section{Study characteristics}

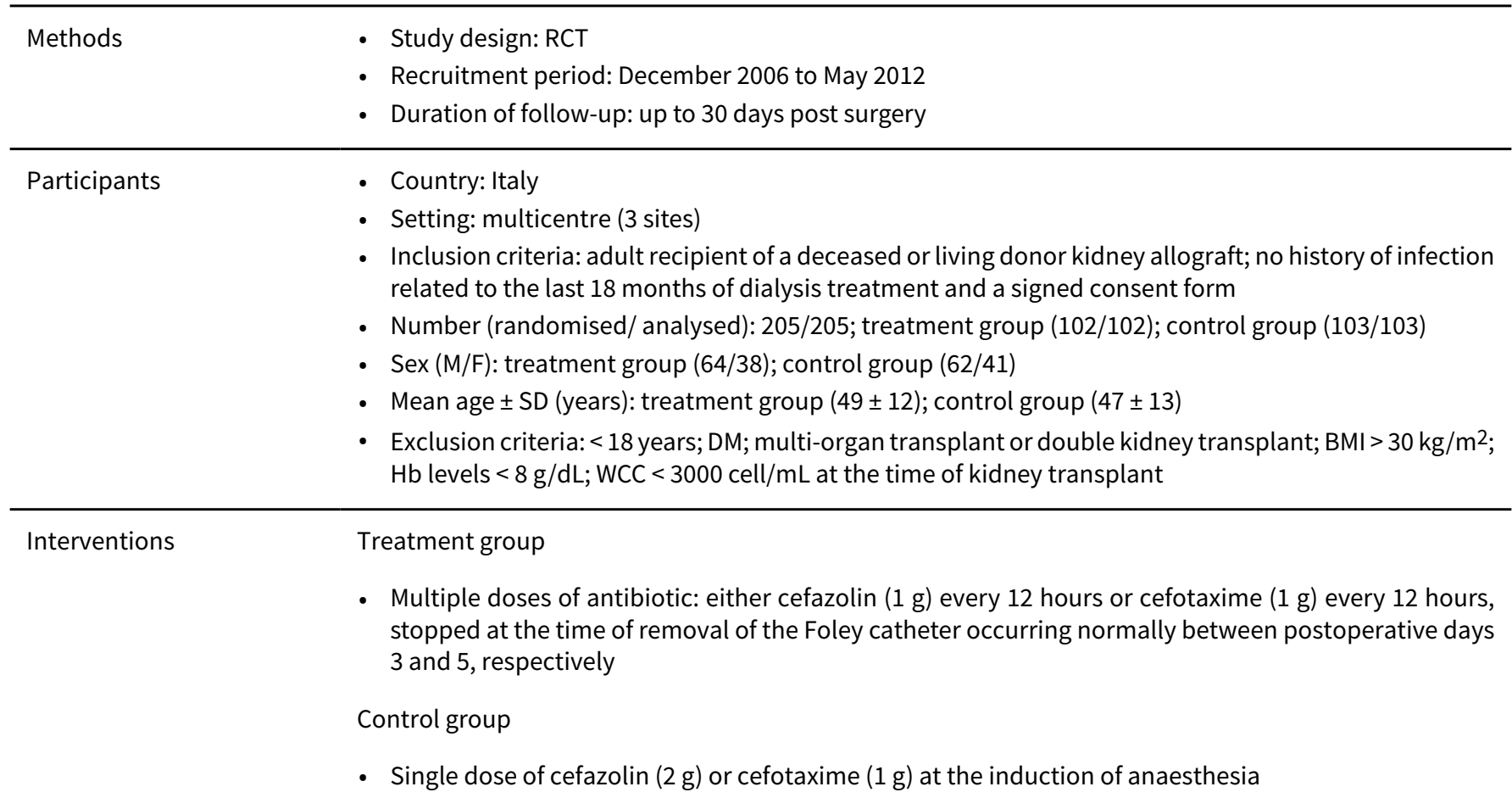


Orlando 2015 (Continued)

\begin{tabular}{ll} 
Outcomes & Primary outcome \\
- Incidence of surgical site infection \\
Secondary outcome \\
- Incidence of other (bacterial, fungal, and viral) infections \\
\hline Notes & - Funding source: not reported
\end{tabular}

\section{Risk of bias}

\begin{tabular}{|c|c|c|}
\hline Bias & Authors' judgement & Support for judgement \\
\hline $\begin{array}{l}\text { Random sequence genera- } \\
\text { tion (selection bias) }\end{array}$ & Low risk & $\begin{array}{l}\text { The article states that "block randomisation by site was determined by a com- } \\
\text { puter-generated scheme" }\end{array}$ \\
\hline $\begin{array}{l}\text { Allocation concealment } \\
\text { (selection bias) }\end{array}$ & Unclear risk & $\begin{array}{l}\text { It is not reported whether allocation concealment was performed in this study; } \\
\text { for example, whether envelopes were used and if they were, whether the en- } \\
\text { velopes used to allocate participants were sealed and sequentially numbered }\end{array}$ \\
\hline $\begin{array}{l}\text { Blinding of participants } \\
\text { and personnel (perfor- } \\
\text { mance bias) } \\
\text { All outcomes }\end{array}$ & High risk & $\begin{array}{l}\text { There is no mention of whether there was blinding of participants and person- } \\
\text { nel in this article }\end{array}$ \\
\hline $\begin{array}{l}\text { Blinding of outcome as- } \\
\text { sessment (detection bias) } \\
\text { All outcomes }\end{array}$ & High risk & There is no mention of whether the outcome assessment was blinded \\
\hline $\begin{array}{l}\text { Incomplete outcome data } \\
\text { (attrition bias) } \\
\text { All outcomes }\end{array}$ & Low risk & All participants completed each outcome assessment \\
\hline $\begin{array}{l}\text { Selective reporting (re- } \\
\text { porting bias) }\end{array}$ & Unclear risk & $\begin{array}{l}\text { Without a study protocol, it is unclear whether any outcomes were measured } \\
\text { but not reported based on the results }\end{array}$ \\
\hline Other bias & Low risk & No other sources of bias identified \\
\hline
\end{tabular}

Robles 1990

\section{Study characteristics}

\begin{tabular}{ll}
\hline Methods & Study design: RCT \\
- Recruitment period: May 1986 to December 1987 \\
- Duration of follow-up: 4 weeks following kidney transplant \\
\hline Participants & Country: Spain \\
- Setting: singe centre \\
- Inclusion criteria: cadaveric kidney transplant patients \\
- Sex (M/F): $39 / 21$ \\
- Mean age \pm SD (years): not reported \\
- Exclusion criteria: receiving antibiotics during the first three weeks for another reason; unable to com- \\
plete the follow-up time
\end{tabular}


Robles 1990 (Continued)

\begin{tabular}{ll} 
Interventions & Treatment group \\
& - Ceftriaxone or cefotaxime \\
Control group & No antimicrobial therapy \\
\hline Outcomes & - Surgical site infections \\
\hline Notes & UTI \\
\hline
\end{tabular}

\section{Risk of bias}

\begin{tabular}{|c|c|c|}
\hline Bias & Authors' judgement & Support for judgement \\
\hline $\begin{array}{l}\text { Random sequence genera- } \\
\text { tion (selection bias) }\end{array}$ & Unclear risk & $\begin{array}{l}\text { The article states that "patients were randomised", but there is no mention of } \\
\text { how the patients were randomised }\end{array}$ \\
\hline $\begin{array}{l}\text { Allocation concealment } \\
\text { (selection bias) }\end{array}$ & Unclear risk & $\begin{array}{l}\text { It is not reported whether allocation concealment was performed in this study; } \\
\text { for example, whether envelopes were used and if they were, whether the en- } \\
\text { velopes used to allocate participants were sealed and sequentially numbered }\end{array}$ \\
\hline $\begin{array}{l}\text { Blinding of participants } \\
\text { and personnel (perfor- } \\
\text { mance bias) } \\
\text { All outcomes }\end{array}$ & High risk & $\begin{array}{l}\text { There is no mention of whether there was blinding of participants and person- } \\
\text { nel in this article }\end{array}$ \\
\hline $\begin{array}{l}\text { Blinding of outcome as- } \\
\text { sessment (detection bias) } \\
\text { All outcomes }\end{array}$ & High risk & There is no mention of whether the outcome assessment was blinded \\
\hline $\begin{array}{l}\text { Incomplete outcome data } \\
\text { (attrition bias) } \\
\text { All outcomes }\end{array}$ & Low risk & All participants completed each outcome assessment \\
\hline $\begin{array}{l}\text { Selective reporting (re- } \\
\text { porting bias) }\end{array}$ & Unclear risk & $\begin{array}{l}\text { Without a study protocol, it is unclear whether any outcomes were measured } \\
\text { but not reported based on the results }\end{array}$ \\
\hline Other bias & Low risk & No other sources of bias identified \\
\hline
\end{tabular}

Townsend 1980

\section{Study characteristics}

\begin{tabular}{ll}
\hline Methods & - Study design: prospective RCT \\
& - Recruitment period: September 1976 to January 1978 \\
\hline Participants & Duration of follow-up: "until discharge from the hospital" \\
& - Country: USA \\
- Setting: single centre \\
- Number (randomised/ analysed): $38 / 37 ;$ treatment group (20); control group (17) \\
- Mean age \pm SD (years): treatment group (34 \pm 6$)$; control group (35 \pm )
\end{tabular}


Townsend 1980 (Continued)

- Sex (M): treatment group (60\%); control group (59\%)

- Exclusion criteria: no reported

\begin{tabular}{ll}
\hline Interventions & Treatment group (first dose of drugs was given two hours prior to surgery) \\
- Cefamandole $1 \mathrm{~g} I \mathrm{M}$ every 6 hours for 8 doses \\
- Tobramycin $1 \mathrm{mg} / \mathrm{kg}$ IM for 1 dose \\
Control group \\
- No antibiotics \\
\hline Outcomes & $\begin{array}{l}\text { Microbiological evidence of infection }(7 \text { days post transplant and during hospitalisation; mean dura- } \\
\text { tion was } 45 \pm 8 \text { days) }\end{array}$ \\
\hline Notes & Funding source: not reported
\end{tabular}

\section{Risk of bias}

\begin{tabular}{|c|c|c|}
\hline Bias & Authors' judgement & Support for judgement \\
\hline $\begin{array}{l}\text { Random sequence genera- } \\
\text { tion (selection bias) }\end{array}$ & Unclear risk & $\begin{array}{l}\text { The article states that "patients were randomised", but there is no mention of } \\
\text { how the patients were randomised }\end{array}$ \\
\hline $\begin{array}{l}\text { Allocation concealment } \\
\text { (selection bias) }\end{array}$ & Unclear risk & $\begin{array}{l}\text { It is not reported whether allocation concealment was performed in this study; } \\
\text { for example, whether envelopes were used and if they were, whether the en- } \\
\text { velopes used to allocate participants were sealed and sequentially numbered }\end{array}$ \\
\hline $\begin{array}{l}\text { Blinding of participants } \\
\text { and personnel (perfor- } \\
\text { mance bias) } \\
\text { All outcomes }\end{array}$ & High risk & $\begin{array}{l}\text { There is no mention of whether there was blinding of participants and person- } \\
\text { nel in this article }\end{array}$ \\
\hline $\begin{array}{l}\text { Blinding of outcome as- } \\
\text { sessment (detection bias) } \\
\text { All outcomes }\end{array}$ & High risk & There is no mention of whether the outcome assessment was blinded \\
\hline $\begin{array}{l}\text { Incomplete outcome data } \\
\text { (attrition bias) } \\
\text { All outcomes }\end{array}$ & Low risk & All participants completed each outcome assessment \\
\hline $\begin{array}{l}\text { Selective reporting (re- } \\
\text { porting bias) }\end{array}$ & Unclear risk & $\begin{array}{l}\text { Without a study protocol, it is unclear whether any outcomes were measured } \\
\text { but not reported based on the results }\end{array}$ \\
\hline Other bias & Low risk & No other sources of bias identified \\
\hline
\end{tabular}

\section{Wilms 1986}

\section{Study characteristics}

\begin{tabular}{ll}
\hline Methods & - Study design: prospective, open-label RCT \\
& - Recruitment period: 1982 \\
& - Duration of follow-up: duration of hospital stay \\
\hline Participants & - Country: Germany \\
& - Setting: single centre
\end{tabular}


Wilms 1986 (Continued)

- Inclusion criteria: 34 consecutive patients receiving cadaveric transplant in single centre.

- Number: treatment group (16); control group (18)

- Mean age \pm SD (years): not reported

- Diabetic (type 1): treatment group (6\%); control group (0\%)

- Exclusion criteria: not reported

\begin{tabular}{ll}
\hline Interventions & Treatment group \\
& - Cephalosporin prophylaxis 2 g pre-transplant and $500 \mathrm{mg}$ at 12,24 and 38 hours \\
& Control group \\
& - No antibiotics \\
\hline Outcomes & - Rejection \\
& - Hospitalisation (days) \\
& - Amount of additional antibiotics for clinical indications \\
& - HD post-transplant (number/patient) \\
\hline Notes & Primary graft function (\%) \\
\hline
\end{tabular}

\section{Risk of bias}

\begin{tabular}{lll}
\hline Bias & Authors' judgement & Support for judgement \\
\hline $\begin{array}{l}\text { Random sequence genera- } \\
\text { tion (selection bias) }\end{array}$ & Unclear risk & Randomisation stipulated as per “randomization plan". Unclear methodology \\
\hline $\begin{array}{l}\text { Allocation concealment } \\
\text { (selection bias) }\end{array}$ & Unclear risk & Allocation process not described \\
\hline $\begin{array}{l}\text { Blinding of participants } \\
\text { and personnel (perfor- } \\
\text { mance bias) } \\
\text { All outcomes }\end{array}$ & High risk & No blinding \\
\hline
\end{tabular}

Blinding of outcome as- High risk Unclear if investigators were blinded

sessment (detection bias)

All outcomes

\begin{tabular}{lll}
\hline $\begin{array}{l}\text { Incomplete outcome data } \\
\text { (attrition bias) } \\
\text { All outcomes }\end{array}$ & High risk & $\begin{array}{l}\text { Missing data reported in bacteriology (both groups), wound healing ( } \mathrm{n}=5 \text { con- } \\
\text { trol), urine leak }(\mathrm{n}=5 \text { control) }\end{array}$ \\
\hline $\begin{array}{l}\text { Selective reporting (re- } \\
\text { porting bias) }\end{array}$ & Unclear risk & $\begin{array}{l}\text { Without a study protocol, it is unclear whether any outcomes were measured } \\
\text { but not reported based on the results }\end{array}$ \\
\hline Other bias & Low risk & No other sources of bias identified \\
\hline
\end{tabular}

BMI - body mass index; DM - diabetes mellitus; GI - gastrointestinal; Hb - haemoglobin; HD - haemodialysis; ICU - intensive care unit; IM intramuscularly; IV - intravenous/ly; M/F - male/female; PD - peritoneal dialysis; RCT - randomised controlled trial; SD - standard deviation; UTI - urinary tract infection; WCC - white cell count

\section{Characteristics of excluded studies [ordered by study ID]}




\begin{tabular}{ll}
\hline Study & Reason for exclusion \\
\hline Hirokawa 2013 & $\begin{array}{l}\text { Wrong population: looking at patients who have had a liver resection (rather than a liver trans- } \\
\text { plant) }\end{array}$ \\
\hline Moreno 1997 & $\begin{array}{l}\text { Wrong population: looking at patients who have already had a kidney transplant and looking at the } \\
\text { efficacy of antimicrobial therapy when patients present with a fever }\end{array}$
\end{tabular}

Salmela 1990 Wrong study design/intervention: study designed to prevent post-operative UTI in kidney transplant recipients, not post-surgical site infections

UTI - urinary tract infection

\section{HISTORY}

Protocol first published: Issue 12, 2018

Review first published: Issue 8, 2020

\section{CONTRIBUTIONS OF AUTHORS}

1. Draft the protocol: $\mathrm{SC}$

2. Study selection: $\mathrm{SC}, \mathrm{SN}, \mathrm{HC}$

3. Extract data from studies: $\mathrm{SC}, \mathrm{SN}, \mathrm{HC}$

4. Enter data into RevMan: SC, SN, HC

5. Carry out the analysis: SC, SN, HC, EP, GW, JC, WL, EP, NI, RF, SBC, CH, DJ

6. Interpret the analysis: SC, SN, HC, EP, JC

7. Draft the final review: SC, SN, HC, EP, GW, JC, WL, EP, NI, RF, SBC, CH, DJ

8. Disagreement resolution: $\mathrm{DJ}$

9. Update the review: SC, SN, HC

\section{DECLARATIONS OF INTEREST}

- Samuel Chan: none known

- Samantha Ng: none known

- Hooi P Chan: none known

- E Geoffrey Playford: none known

- Germaine Wong: none known

- Jeremy R Chapman: none known

- Wai H Lim: has received funding from Astellas, Novartis and Alexion for advisory board memberships; speakers' fees from Astellas and Alexion and an education grant from Novartis

- Elaine M Pascoe: none known

- Nicole M Isbel: has received funding for participation in advisory boards and provision of educational lectures from Alexion Pharmaceuticals and Amgen on topics that are unrelated to this review

- Ross S Francis: has received support with travel expenses to attend conferences from Novartis and Amgen

- Scott B Campbell: none known

- Carmel M Hawley: has received fees from GlaxoSmithKline, Amgen, Shire, Roche, Abbott, Bayer, Fresenius, Baxter, Gambro, Janssen and Genzyme in relation to consultancy, speakers' fees, education, and grants for activities unrelated to this review

- David W Johnson: has previously received consultancy fees, research grants, speaker's honoraria and travel sponsorships from Baxter Healthcare and Fresenius Medical Care. He has also received consultancy fees from AstraZeneca and travel sponsorships from Amgen

\section{DIFFERENCES BETWEEN PROTOCOLAND REVIEW}

There have been no changes made between the Cochrane protocol and review. 